Article

\title{
Antioxidants and Health-Beneficial Nutrients in Fruits of Eighteen Cucurbita Cultivars: Analysis of Diversity and Dietary Implications
}

\author{
Anna Kostecka-Gugała *(D), Michał Kruczek, Iwona Ledwożyw-Smoleń and Paweł Kaszycki *iD \\ Department of Plant Biology and Biotechnology, Faculty of Biotechnology and Horticulture, University of \\ Agriculture in Krakow, al.29 Listopada 54, 31-425 Kraków, Poland; kruczek.michael@gmail.com (M.K.); \\ iwona.ledwozyw-smolen@urk.edu.pl (I.L.-S.) \\ * Correspondence: anna.kostecka-gugala@urk.edu.pl (A.K.-G.); pawel.kaszycki@urk.edu.pl (P.K.)
}

Academic Editor: Susana M. Cardoso

Received: 19 March 2020; Accepted: 9 April 2020; Published: 14 April 2020

\begin{abstract}
Aging is accompanied by gradual accumulation of molecular damage within cells in response to oxidative stress resulting from adverse environmental factors, inappropriate lifestyle, and numerous diseases. Adequate antioxidant intake is a key factor of proper diet. The study aimed to assess the antioxidant/antiradical capacities of Cucurbita fruits (18 cultivars of the species: C. maxima Duch., C. moschata Duch., C. pepo L., and C. ficifolia Bouché) grown in central Europe. The analyses were based on the FRAP (ferric reducing antioxidant power), CUPRAC (cupric ion reducing antioxidant capacity), and DPPH (2,2-diphenyl-1-picrylhydrazyl radical) assays. The content of phenolic compounds and $\beta$-carotene was evaluated with HPLC (high performance liquid chromatography), while the main macro- and micronutrients by ICP-OES (inductively coupled plasma mass spectrometry). The results revealed high intraspecies variability within the Cucurbita genus. The Japanese 'Kogigu' fruits were distinguished as extraordinary sources of phenolic compounds, including syringic and protocatechuic acids, catechin, and kaempferol. Another popular cultivar 'Hokkaido' exhibited the highest antioxidant and antiradical capacities. Most of the fruits proved to be rich sources of zinc and copper. The obtained data are discussed in the context of optimized nutrition of the elderly and suggest that Cucurbita fruits should become daily components of their diet.
\end{abstract}

Keywords: pumpkin; squash; Cucurbitaceae; polyphenols; carotenoids; micronutrients; bioactive compounds; antiradical capacity; functional food; aging

\section{Introduction}

Pumpkin and squash are common dish ingredients in South America, China, southern Asia, and Japan. They are also used in North American cuisines and are well known in Western Europe. However, in the central and eastern European countries they became partly forgotten and mainly associated with puree juice and soup for the youngest children.

These vegetables belong to the Cucurbita genus and they are among the oldest domesticated plants, used as early as ca. 10,000 B.P. [1] on the territory of contemporary Mexico and Guatemala, predating corn and beans by more than 4000 years [1,2]. In the 16th century they were introduced in Europe [3,4] and since then rapidly spread worldwide [5]. Cucurbitaceae family consists of more than 900 species and Cucurbita comprises 14 species with six subspecies and two wild varieties [6,7]. The family contains also cucumbers, gourds, melons, watermelons, chilacayotes, and others. The cultivated cucurbits are quite similar in terms of their requirements for growth and development but their fruit morphology (sizes, shapes, colors, pulp structure) is highly variable [2]. Cucurbits are known to reveal wide range of medicinal properties and therefore are recognized as a functional food [8-10]. A number of their 
biologically active compounds were investigated for cytotoxic, hepatoprotective, anti-inflammatory, and cardiovascular properties [11]. For that reason, they may also be regarded as healthy food for healthy aging. It has to be realized that the aging society requires substantial changes in both the nutrient demands and ways of alimentation. It also brings numerous chronically ill patients and leads to increased incidence of comorbidities including hypertension, atherosclerosis, cardiovascular disease, age-related eye diseases, obesity, type II diabetes, neurodegenerative disorders, and cancer.

The group of the elderly (65+ years old) is growing rapidly and for people aged $80+$ their population is predicted to exceed 400 million by 2050 [12]. In 1999, the first "Modified Food Guide Pyramid" for adults aged 70+ was proposed [13]. It was constructed assuming that the narrower base reflects a decrease in energy needs, while emphasizing the importance of nutrient-dense foods, dietary fiber, and water. In addition, nutrient-specific supplements appropriate for older people, e.g., deeply colored fruits and vegetables were recommended. It was highlighted that they should be consumed as a whole fiber-rich food [13]. Recent studies based on HEI-2015 (Healthy Eating Index) [14,15] revealed a positive trend in the nutrition of older Americans. On the contrary, research on the diet of older inhabitants of Switzerland showed that only 38\% of this group complied with "The Swiss Food Pyramid" indicating a need for lifelong education in this area [16]. Building social awareness of specific dietary needs of the elderly has become an urgent and challenging task for researchers and physicians.

All parts of Cucurbitaceae plants are edible and therefore they are grown for seeds, flowers, roots, leaves, and fruits. Flowers (of squash and pumpkins) and roots (of chayote) are ingredients in traditional cuisines [17]. Seeds can be consumed raw or roasted, and may also serve as material for cooking oil, rich in biologically active compounds [18]. In several world regions, C. pepo seeds are used in traditional medicine to cure urinary and prostate diseases or as anti-inflammatory, antipyretic, and analgesic remedies. Their antioxidant and lipoxygenase inhibitory activities are well documented [19]. Fruits, in turn, are used when collected at various stages of maturity and can be cooked, baked, pickled, candied or consumed raw. Infusions and decoctions made of Cucurbita fruits in traditional medicine are believed to alleviate cold and ache $[11,17,20,21]$. Note that cucurbits are easily digestible and have soft and delicate textures, which are the features especially important for seniors, particularly the ones with masticatory/swallowing dysfunctions and/or special nutrition needs [12]. The treatment with C. pepo fruit pulp extract showed an increase in alkaline phosphatase activity and mucosal thickness which confirmed its gastroduodenal protective and anti-ulcerogenic properties [22]. Pumpkin is considered as a good source of anti-inflammatory substances found helpful in many diseases such as arthritis $[23,24]$.

Cucurbita fruits are rich in phenolic compounds: protocatechuic, chlorogenic, salicylic, p-hydroxybenoic, $p$-cumaric acids, eriodictyol-7-neohesperidoside, and hesperidin [25]. Foods rich in polyphenols, in particular flavonoids, were shown to modify endothelial formation of $\mathrm{NO}$ and to improve endothelium function in humans [26]. Polyphenols were also found to positively influence neuronal cells by attenuating oxidative stress and damage in Alzheimer's and Parkinson's diseases as well as in amyotrophic lateral sclerosis [27]. Clinical manifestations of many neurodegenerative diseases are associated with ageing; however, the onset of neuronal death progresses through life [28].

Most of anti-cancer properties of Cucurbita concern seeds and seed oil; however, several studies revealed anti-carcinogenic potential of fruit-borne compounds. Cucurbita polysaccharide named PPPF directly induced apoptosis of HepG2 cells due to down-regulation of the signal transduction pathways, and this mechanism was proposed to facilitate the development of a therapeutic strategy for treating human hepatoma [29]. Cucurbitacins are triterpene secondary metabolites shown to induce apoptosis of various cancer cell lines [17,30] and to arrest the cell cycle at the G2/M phase [31,32]. Note, however, that the role of numerous antioxidants including polyphenols found in Cucurbita fruits, in anti-tumor action is still unclear.

Yellow to dark-orange colors of Cucurbita fruits result from high content of carotenoids, mainly $\beta$-carotene and/or lutein as well as zeaxanthin [33-35]. These carotenoids play an essential role in maintaining ocular health status [36]; $\beta$-carotene is a precursor of 11-cis retinal, a chromophore of rhodopsin found in rods, receptors enabling vision under low-light conditions. Lutein and zeaxanthin 
are the main antioxidants of retina, absorbing UV radiation and blue light as well as scavenging free radicals and reactive oxygen species (ROS). The oxidative stress caused by the mentioned radiation contributes to the aging processes resulting, among others, in eye diseases such as age-related macular degeneration (AMD) and cataract [36]. Prevention and treatment of age-related eye diseases includes carotenoid supplementation.

The common feature of the Cucurbita pulp is its low content of fat (about 2.3\% in C. pepo) [21] and low glycemic index due to the high content of dietary fiber, especially pectins [37]. Cucurbits were shown to reduce the need for insulin in diabetic patients [38]. Many studies confirmed the hypoglycemic efficacy of various polysaccharides found in the pulp $[39,40]$. Furthermore, the research on animal and human models revealed that treatment with some pumpkin extracts, e.g. C. moschata, had hypoglycemic and other anti-diabetic effects as well as stimulated regeneration of pancreatic $\beta$-cells [41,42]. C. ficifolia (fig-leaf gourd) was even listed within a group of the best anti-obesity medicinal plants due to ability to reduce systemic chronic inflammation accompanying obesity [43]. The results obtained upon the consumption of cucurbit fruits were comparable with those of commonly prescribed anti-diabetic drugs [41].

This study was aimed to assess the antioxidant potential and other health-beneficial properties of fruits of 18 cultivars of four species: Cucurbita maxima Duchesne, C. pepo L., C. moschata Duchesne, and C. ficifolia Bouché successfully planted under temperate climate conditions of central Europe. The research is expected to expand current knowledge on the health-promoting potential of Cucurbita fruits, especially in the context of dietary requirements of the elderly as well as patients suffering from chronic diseases.

\section{Results}

The highest content of total phenolic compounds (TPC, expressed as chlorogenic equivalents, $\mathrm{CAE}$, in mg per $100 \mathrm{~g}$ of fresh weight) was found in the fruits of C.moschata 'Kogigu' (70.8 mg) (Table 1). That cultivar was also characterized by the highest contents of the following phenolics (given in $\mathrm{mg}$ per $100 \mathrm{~g}$ of fresh weight): protocatechuic $(2.42 \mathrm{mg})$, syringic $(16.41 \mathrm{mg})$ and ferulic $(0.442 \mathrm{mg})$ acids, catechin $(0.52 \mathrm{mg})$, and kaempferol $(0.107 \mathrm{mg})$. High level of protocatechuic acid was also found in the fruits of 'Shishigatani' (1.70 mg) (Table 2 and Figure S1).

Among the analyzed C. maxima cultivars, 'Indomatrone' and 'Bambino' were characterized by a substantially high level of total phenols-i.e., 50.4 and $41.6 \mathrm{mg}$ - respectively. In addition, 'Indomatrone' fruits contained one of the highest levels of salicylic acid $(2.56 \mathrm{mg})$, comparable only to the value noted for 'Table Gold' of C. pepo (2.74 mg). On the other hand, three of the analyzed cultivars, i.e., 'Chicago Warted Hubbard', 'Garbo', and 'Triamble' contained significant amounts of catechin.

For C. pepo, the highest levels of total phenolics were noted in the fruits of 'KamoKamo' (51.5 mg) and 'Sweet Dumpling' ( $48.1 \mathrm{mg}$ ) cultivars. The latter one was also characterized by high accumulation of syringic acid $(7.70 \mathrm{mg})$. The content of total as well as individual phenolic compounds in the fruits of C. ficifolia 'Angel Hair' was at a relatively low level. 
Table 1. Antioxidant capacity and the content of $\beta$-carotene, phenolic compounds, soluble sugars, and free amino acids in the pulp of $18 \mathrm{Cucurbita}$ cultivars.

\begin{tabular}{|c|c|c|c|c|c|c|c|c|}
\hline & & & $\begin{array}{l}\text { ioxidant Capa } \\
\text { TE } 100 \mathrm{~g}^{-1} \text { f.w. }\end{array}$ & & 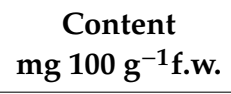 & CAE $100 \mathrm{~g}^{-1}$ f.w. & g $100 \mathrm{~g}^{-1}$ f.w. & $\mathrm{mg} 100 \mathrm{~g}^{-1}$ f.w. \\
\hline Species & Cultivar & CUPRAC & FRAP & DPPH & $\beta$-Carotene & Total phenols & Soluble sugars & Amino acids \\
\hline \multirow[t]{8}{*}{ C. maxima } & Australian Butter & $193.6 \pm 11.2 \mathrm{~g}$ & $50.9 \pm 3.5^{\mathrm{ef}}$ & $2.90 \pm 0.50 \mathrm{abc}$ & $13.1 \pm 0.5^{\text {cde }}$ & $19.7 \pm 0.9^{a b c}$ & $6.43 \pm 0.38^{\mathrm{e}}$ & $57.8 \pm 1.2^{\mathrm{e}}$ \\
\hline & Bambino & $118.4 \pm 10.6^{\text {de }}$ & $40.5 \pm 9.8^{\text {cde }}$ & $13.07 \pm 2.27 \mathrm{def}$ & n.a. & $41.6 \pm 4.2^{\mathrm{fgh}}$ & $7.89 \pm 0.29 \mathrm{~g}$ & $63.4 \pm 1.7^{\text {ef }}$ \\
\hline & Buttercup & 130. $\pm 19.3^{\mathrm{e}}$ & $41.3 \pm 1.8^{\text {cde }}$ & $5.76 \pm 1.00^{a b c}$ & n.a. & $36.0 \pm 2.8^{\text {efg }}$ & $4.30 \pm 0.18^{b c d}$ & $35.3 \pm 0.1^{d}$ \\
\hline & $\begin{array}{c}\text { Chicago Warted } \\
\text { Hubbard }\end{array}$ & $109.3 \pm 3.4$ bcde & $33.6 \pm 1.3^{b c d}$ & $8.86 \pm 1.54^{\text {cde }}$ & $12.7 \pm 0.6^{\text {cde }}$ & $18.9 \pm 2.0^{\mathrm{abc}}$ & $6.90 \pm 0.09^{\mathrm{ef}}$ & $64.2 \pm 5.1^{\text {ef }}$ \\
\hline & Garbo & $99.4 \pm 3.8^{\mathrm{bcd}}$ & $22.3 \pm 0.8^{\mathrm{ab}}$ & $1.58 \pm 0.27^{\mathrm{ab}}$ & $11.9 \pm 0.5^{\mathrm{cd}}$ & $27.6 \pm 1.8$ bcde & $4.36 \pm 0.35^{b c d}$ & $23.1 \pm 2.3^{b c}$ \\
\hline & Hokkaido & $251.5 \pm 20.3^{h}$ & $139.9 \pm 13.1^{\mathrm{i}}$ & $32.46 \pm 1.06^{\mathrm{i}}$ & n.a. & $20.6 \pm 0.5^{a b c}$ & $6.10 \pm 0.62^{\mathrm{e}}$ & $109.5 \pm 6.7^{g}$ \\
\hline & Indomatrone & $256.6 \pm 2.6^{h}$ & $85.2 \pm 2.9^{h}$ & $1.01 \pm 0.03^{\mathrm{a}}$ & $14.8 \pm 0.9^{\mathrm{e}}$ & $50.4 \pm 3.1^{\mathrm{h}}$ & $7.34 \pm 0.25^{\mathrm{fg}}$ & $71.3 \pm 7.0^{\mathrm{f}}$ \\
\hline & Triamble & $114.7 \pm 3.7^{\text {cde }}$ & $21.2 \pm 3.6^{\mathrm{ab}}$ & $3.57 \pm 0.62^{a b c}$ & $11.2 \pm 0.2^{\mathrm{c}}$ & $32.5 \pm 1.9$ def & $4.97 \pm 0.03^{\mathrm{d}}$ & $27.2 \pm 2.2^{\mathrm{cd}}$ \\
\hline \multirow[t]{5}{*}{ C. реро } & Halloween & $64.3 \pm 3.6^{\mathrm{a}}$ & $11.7 \pm 1.7^{\mathrm{a}}$ & $3.31 \pm 0.57 \mathrm{abc}$ & $11.5 \pm 0.2^{c}$ & $21.3 \pm 2.2 \mathrm{abcd}$ & $3.03 \pm 0.27^{a}$ & $25.9 \pm 1.6^{\mathrm{cd}}$ \\
\hline & Kamo Kamo & $168.8 \pm 1.4^{\mathrm{fg}}$ & $57.8 \pm 3.8^{\mathrm{f}}$ & $21.03 \pm 3.65 \mathrm{gh}$ & $1.9 \pm 0.0^{\mathrm{a}}$ & $51.5 \pm 11.0^{h}$ & $3.64 \pm 0.26^{a b c}$ & $15.5 \pm 1.2^{\mathrm{ab}}$ \\
\hline & Miranda & $102.7 \pm 6.8^{\text {bcde }}$ & $33.0 \pm 0.8^{b c d}$ & $13.92 \pm 0.45$ ef & $7.6 \pm 0.8^{b}$ & $13.2 \pm 0.6^{\mathrm{a}}$ & $6.35 \pm 0.36^{\mathrm{e}}$ & $22.6 \pm 0.9^{b c}$ \\
\hline & Sweet Dumpling & $178.6 \pm 16.1 \mathrm{fg}$ & $51.2 \pm 3.1$ ef & $32.10 \pm 5.56^{\mathrm{i}}$ & $14.6 \pm 0.6^{\mathrm{e}}$ & $48.1 \pm 1.8^{h}$ & $2.78 \pm 0.13^{\mathrm{a}}$ & $12.7 \pm 2.5 \mathrm{a}$ \\
\hline & Table Gold & $173.1 \pm 8.1 \mathrm{fg}$ & $33.4 \pm 3.1 \mathrm{bcd}$ & $5.64 \pm 0.98 \mathrm{abc}$ & $14.4 \pm 0.3^{\mathrm{e}}$ & $29.8 \pm 3.1$ cde & $4.38 \pm 0.05^{\mathrm{bcd}}$ & $28.1 \pm 1.2^{b c}$ \\
\hline \multirow[t]{4}{*}{ C. moschata } & Butternut & $83.1 \pm 4.7^{a b}$ & $21.7 \pm 2.5^{\mathrm{ab}}$ & $2.45 \pm 0.35^{\mathrm{ab}}$ & $11.1 \pm 0.6^{\mathrm{c}}$ & $17.1 \pm 1.1^{\mathrm{ab}}$ & $4.49 \pm 0.13^{\mathrm{cd}}$ & $64.7 \pm 3.7$ ef \\
\hline & Kogigu & $158.8 \pm 2.0^{\mathrm{f}}$ & $34.7 \pm 2.4^{b c d}$ & $7.78 \pm 1.35 \mathrm{bcd}$ & $14.3 \pm 2.3^{\mathrm{de}}$ & $70.8 \pm 6.3^{i}$ & $6.71 \pm 0.36^{\text {ef }}$ & $59.5 \pm 3.2^{\mathrm{e}}$ \\
\hline & Musquéede Provence & $86.1 \pm 1.9^{a b c}$ & $31.9 \pm 1.7 \mathrm{bc}$ & $16.08 \pm 2.79 \mathrm{fg}$ & $0.5 \pm 0.1^{\mathrm{a}}$ & $29.2 \pm 0.6^{\text {cde }}$ & $3.50 \pm 0.04^{\mathrm{ab}}$ & $7.6 \pm 0.5^{\mathrm{a}}$ \\
\hline & Shishigatani & $194.8 \pm 9.1 \mathrm{~g}$ & $47.9 \pm 4.6^{\text {def }}$ & $15.01 \pm 1.02^{\mathrm{f}}$ & $12.5 \pm 0.6^{\text {cde }}$ & $46.6 \pm 2.1 \mathrm{gh}$ & $4.66 \pm 0.23^{\mathrm{d}}$ & $56.2 \pm 2.7^{\mathrm{e}}$ \\
\hline C. ficifolia & Angel Hair & $233.3 \pm 4.7^{\mathrm{h}}$ & $71.4 \pm 4.4^{g}$ & $24.52 \pm 0.86^{\mathrm{h}}$ & n.a. & $20.6 \pm 0.1^{\mathrm{abc}}$ & $4.56 \pm 0.24^{\mathrm{d}}$ & $13.0 \pm 0.2^{\mathrm{a}}$ \\
\hline
\end{tabular}

The values are given as means \pm standard errors, followed by the letters a-i (in superscripts) to indicate statistical significance. The values marked with the same letters in one column are not statistically different at the $p<0.05 ; n=3$; n.a., not analyzed. 
Table 2. Content of selected phenolic compounds in the pulp of 18Cucurbita cultivars.

\begin{tabular}{|c|c|c|c|c|c|c|c|c|c|c|c|}
\hline \multirow[b]{2}{*}{ Species } & \multirow[b]{2}{*}{ Cultivar } & \multicolumn{10}{|c|}{ Content (mg $100 \mathrm{~g}^{-1}$ f.w.) } \\
\hline & & $\begin{array}{l}\text { Protocatechuic } \\
\text { Acid }\end{array}$ & $\begin{array}{c}p \text {-hydroxy-Benzoic } \\
\text { Acid } \\
\end{array}$ & Catechin & $\begin{array}{l}\text { Chlorogenic } \\
\text { Acid }\end{array}$ & $\begin{array}{c}\text { Caffeic } \\
\text { Acid }\end{array}$ & $\begin{array}{c}p \text {-Coumaric } \\
\text { Acid }\end{array}$ & Syringic Acid & Ferulic Acid & $\begin{array}{l}\text { Salicylic } \\
\text { Acid }\end{array}$ & Kaempferol \\
\hline \multirow[t]{8}{*}{ C. maxima } & Australian Butter & $0.69 \pm 0.09 \mathrm{~d}$ & $0.003 \pm 0.001$ & $0.06 \pm 0.01 \mathrm{abc}$ & n.d. & n.d. & $0.02 \pm 0.003$ & $1.29 \pm 0.03 \mathrm{abc}$ & $0.012 \pm 0.000$ & $1.39 \pm 0.12 \mathrm{e}$ & $0.025 \pm 0.002$ \\
\hline & Bambino & $0.09 \pm 0.00 \mathrm{ab}$ & $0.007 \pm 0.000$ & $0.15 \pm 0.02 \mathrm{bc}$ & n.d. & $0.03 \pm 0.00$ & $0.02 \pm 0.004$ & $4.43 \pm 0.26^{\text {ef }}$ & n.d. & $1.43 \pm 0.30^{\mathrm{e}}$ & n.d. \\
\hline & Buttercup & $0.36 \pm 0.02^{c}$ & $0.001 \pm 0.000$ & $0.03 \pm 0.01^{\mathrm{a}}$ & n.d. & $0.05 \pm 0.00$ & & $2.04 \pm 0.24 \mathrm{bc}$ & & $0.10 \pm 0.02^{\mathrm{a}}$ & $0.046 \pm 0.001$ \\
\hline & $\begin{array}{c}\text { Chicago Warted } \\
\text { Hubbard }\end{array}$ & $0.29 \pm 0.05^{b c}$ & $0.027 \pm 0.000$ & $0.38 \pm 0.03 \mathrm{~g}$ & n.d. & $0.05 \pm 0.02$ & $0.03 \pm 0.004$ & $1.46 \pm 0.12 \mathrm{abc}$ & $0.231 \pm 0.060$ & $1.76 \pm 0.15^{\mathrm{f}}$ & $0.042 \pm 0.009$ \\
\hline & Garbo & $0.52 \pm 0.01^{\mathrm{cd}}$ & $0.004 \pm 0.001$ & $0.42 \pm 0.04 \mathrm{~g}$ & n.d. & n.d. & $0.03 \pm 0.004$ & $4.54 \pm 0.21$ ef & $0.259 \pm 0.011$ & $1.66 \pm 0.09$ ef & $0.056 \pm 0.006$ \\
\hline & Hokkaido & $1.16 \pm 0.02^{\mathrm{e}}$ & $0.001 \pm 0.000$ & $0.02 \pm 0.00^{\mathrm{a}}$ & n.d. & $0.04 \pm 0.00$ & n.d. & $0.62 \pm 0.03^{a b}$ & $0.020 \pm 0.004$ & $0.68 \pm 0.02^{b c}$ & $0.042 \pm 0.003$ \\
\hline & Indomatrone & $0.66 \pm 0.01^{\mathrm{d}}$ & $0.020 \pm 0.002$ & $0.06 \pm 0.00 \mathrm{ab}$ & n.d. & n.d. & $0.02 \pm 0.003$ & $4.25 \pm 0.19$ ef & $0.020 \pm 0.002$ & $2.56 \pm 0.12 \mathrm{~g}$ & $0.060 \pm 0.009$ \\
\hline & Triamble & $0.03 \pm 0.00^{\mathrm{a}}$ & $0.006 \pm 0.000$ & $0.37 \pm 0.01 \mathrm{~g}$ & $0.03 \pm 0.00$ & n.d. & $0.01 \pm 0.002$ & $2.77 \pm 0.10^{\mathrm{cd}}$ & $0.143 \pm 0.014$ & $1.49 \pm 0.11$ ef & n.d. \\
\hline \multirow[t]{5}{*}{ C. pepo } & Halloween & $1.07 \pm 0.10^{\mathrm{e}}$ & $0.002 \pm 0.001$ & $0.22 \pm 0.02$ ef & $0.14 \pm 0.02$ & $0.03 \pm 0.01$ & $0.01 \pm 0.001$ & $2.18 \pm 0.05^{b c}$ & $0.010 \pm 0.001$ & $1.06 \pm 0.04^{\mathrm{d}}$ & $0.027 \pm 0.003$ \\
\hline & KamoKamo & $1.08 \pm 0.08^{\mathrm{e}}$ & $0.002 \pm 0.000$ & $0.15 \pm 0.02$ cde & n.d. & $0.01 \pm 0.00$ & n.d. & $4.91 \pm 0.16^{\mathrm{ef}}$ & $0.025 \pm 0.001$ & $0.61 \pm 0.03^{b c}$ & $0.022 \pm 0.001$ \\
\hline & Miranda & $1.46 \pm 0.06^{\mathrm{f}}$ & $001 \pm 0.000$ & $0.09 \pm 0.00 \mathrm{abc}$ & $0.02 \pm 0.00$ & $0.04 \pm 0.00$ & $0.02 \pm 0.002$ & $1.47 \pm 0.14 \mathrm{abc}$ & $0.015 \pm 0.003$ & $0.43 \pm 0.04^{b}$ & n.d. \\
\hline & Sweet Dumpling & $0.42 \pm 0.03^{c}$ & $0.002 \pm 0.000$ & n.d & $0.06 \pm 0.00$ & n.d. & $0.01 \pm 0.000$ & $7.70 \pm 0.72 \mathrm{~g}$ & $0.072 \pm 0.013$ & $0.12 \pm 0.01^{\mathrm{a}}$ & n.d. \\
\hline & Table Gold & $1.03 \pm 0.11^{\mathrm{e}}$ & $0.004 \pm 0.000$ & $0.19 \pm 0.00 \mathrm{de}$ & n.d. & n.d. & $0.01 \pm 0.003$ & $2.14 \pm 0.08^{b c}$ & n.d. & $2.74 \pm 0.09 \mathrm{~g}$ & n.d. \\
\hline \multirow[t]{4}{*}{ C. moschata } & Butternut & $1.03 \pm 0.07 \mathrm{e}$ & $0.009 \pm 0.000$ & $0.28 \pm 0.01^{\mathrm{f}}$ & n.d. & n.d. & $0.02 \pm 0.00$ & $0.84 \pm 0.05^{\mathrm{ab}}$ & $0.196 \pm 0.009$ & $0.82 \pm 0.02^{\mathrm{cd}}$ & $0.048 \pm 0.008$ \\
\hline & Kogigu & $2.42 \pm 0.20^{\mathrm{h}}$ & $0.014 \pm 0.000$ & $0.52 \pm 0.06^{\mathrm{h}}$ & n.d. & $0.04 \pm 0.00$ & $0.03 \pm 0.006$ & $16.41 \pm 1.77^{\mathrm{h}}$ & $0.442 \pm 0.005$ & $0.50 \pm 0.04^{b c}$ & $0.107 \pm 0.043$ \\
\hline & $\begin{array}{l}\text { Musquéede } \\
\text { Provence }\end{array}$ & $0.32 \pm 0.06^{b c}$ & $0.003 \pm 0.000$ & n.d. & n.d. & n.d. & n.d. & $3.72 \pm 0.51 \mathrm{de}$ & n.d. & $0.50 \pm 0.13^{b c}$ & $0.026 \pm 0.003$ \\
\hline & Shishigatani & $1.70 \pm 0.15 \mathrm{~g}$ & $0.015 \pm 0.000$ & $0.13 \pm 0.03$ bcde & $0.03 \pm 0.00$ & $0.08 \pm 0.01$ & $0.02 \pm 0.001$ & $5.42 \pm 0.36^{\mathrm{f}}$ & n.d. & $0.45 \pm 0.02^{b}$ & n.d. \\
\hline C. ficifolia & Angel Hair & $0.27 \pm 0.02 \mathrm{bc}$ & $0.004 \pm 0.000$ & $0.12 \pm 0.00 \mathrm{bcd}$ & n.d. & $0.03 \pm 0.00$ & n.d. & $0.39 \pm 0.06^{\mathrm{a}}$ & n.d. & $0.04 \pm 0.00^{\mathrm{a}}$ & n.d. \\
\hline
\end{tabular}

The values are given as means \pm standard errors, followed by the letters a-h (in superscripts) to indicate statistical significance. The values marked with the same letters in one column are not statistically different at the $p<0.05 ; n=3$; n.a., not analyzed. The order of the compounds corresponds to the order of retention times (HPLC). 
The highest concentrations of $\beta$-carotene (between 12.5-14.6 mg $100 \mathrm{~g}^{-1} \mathrm{f} . \mathrm{w}$.) (Table 1) were found in the fruits of 'Indomatrone', 'Australian Butter', 'Chicago Warted Hubbard' (C. maxima), 'Sweet Dumpling', and 'Table Gold' (C. pepo) as well as 'Kogigu' and 'Shishigatani' (C. moschata). Fruits of 'Musquée de Provence' (C. moschata) and 'KamoKamo' (C. pepo) contained the lowest levels of that carotene among all analyzed cultivars-i.e., 0.5 and $1.9 \mathrm{mg} 100 \mathrm{~g}^{-1}$ f.w.-respectively.

The analysis of the antioxidant potential of Cucurbita fruits revealed significant differentiation with respect to both the tested cultivar and applied assay (Table 1). The highest values of antioxidant capacity measured by all three assays and expressed as Trolox equivalents, TE, per $100 \mathrm{~g}$ of fresh weight were obtained for 'Hokkaido' (C. maxima) and 'Angel Hair' (C. ficifolia). Interestingly, pumpkin fruits of 'Indomatrone' (C. maxima) were characterized by high values of FRAP (85.2 TE) and CUPRAC (256.6 TE) but revealed an exceptionally low antioxidant capacity as measured by the DPPH assay (1.01 TE). Conversely, 'Musquée de Provence' (C. moschata) fruits exhibited relatively high DPPH values (16.08 TE) and low antioxidant potential as measured by FRAP (31.9 TE) and CUPRAC (86.1 TE) assays when compared to other cultivars. Fruits of 'Sweet Dumpling' (C. pepo) produced substantially high antiradical scavenging activity (32.10 TE). The lowest values of antioxidant capacity as measured by all three methods were documented for: 'Butternut' (C. moschata), 'Halloween' (C. pepo), and 'Garbo' (C. maxima).

Correlation matrix was constructed to analyze the relation between the content of selected compounds exhibiting antioxidant properties and the values of antioxidant capacities for all the analyzed cultivars (Table 3). A positive correlation between the content of total phenolic compounds and antioxidant capacity as measured by $\operatorname{FRAP}\left(r=0.46^{*}\right)$ and CUPRAC $\left(r=0.54^{* *}\right)$ methods was revealed. Contrarily, the content of catechin was negatively correlated with FRAP $\left(r=-0.54{ }^{* * *}\right)$ and CUPRAC $\left(r=-0.44^{*}\right)$ values of pumpkin fruits. Interestingly, the negative relation was also found for concentration of $\beta$-carotene (as well as salicylic acid) and antiradical scavenging activity $\left(r=-0.65^{* * *}\right.$ and $r=0.53^{* * *}$, respectively). The content of syringic acid was positively correlated with that of protocatechuic acid $\left(r=0.64^{* * *}\right)$ and total phenols $\left(r=0.78^{* * *}\right)$. High value of correlation coefficient for the antioxidant capacities measured by FRAP and CUPRAC $\left(r=0.89^{* * *}\right)$ confirms the similarity of the tested methods with respect to the mechanism of action.

Table 3. Correlation matrix for selected antioxidant parameters of fruit pulp of Cucurbita cultivars.

\begin{tabular}{|c|c|c|c|c|c|c|c|c|c|c|}
\hline & TP & FRAP & CUPRAC & DPPH & Car & PcA & $\mathrm{pHbA}$ & SyrA & SA & Cat \\
\hline $\mathrm{TP}$ & 1.00 & & & & & & & & & \\
\hline FRAP & 0.46 * & 1.00 & & & & & & & & \\
\hline CUPRAC & $0.54 * * *$ & $0.89 * * *$ & 1.00 & & & & & & & \\
\hline DPPH & 0.32 & 0.22 & 0.10 & 1.00 & & & & & & \\
\hline Car & 0.05 & -0.03 & 0.23 & $-0.65 * * *$ & 1.00 & & & & & \\
\hline PcA & 0.48 * & 0.05 & 0.13 & 0.39 & -0.02 & 1.00 & & & & \\
\hline $\mathrm{pHbA}$ & 0.25 & 0.31 & 0.29 & -0.07 & $0.44 *$ & -0.05 & 1.00 & & & \\
\hline SyrA & $0.78 * * *$ & 0.12 & 0.24 & 0.13 & 0.15 & $0.64 * * *$ & 0.23 & 1.00 & & \\
\hline SA & -0.11 & 0.23 & 0.32 & $-0.53 * * *$ & $0.49 *$ & $-0.57 * * *$ & 0.21 & -0.30 & 1.00 & \\
\hline Cat & 0.17 & $-0.54 * * *$ & $-0.44 *$ & -0.22 & 0.17 & 0.01 & 0.26 & $0.51 *$ & -0.08 & 1.00 \\
\hline
\end{tabular}

Abbreviations: TP-total phenols, FRAP-ferric reducing antioxidant capacity, CUPRAC—cupric reducing antioxidant capacity, DPPH-diphenyl picrylhydrazyl radical scavenging activity, Car- $\beta$-carotene, PcA—protocatechuic acid, $\mathrm{pHbA} — p$-hydroxybenzoic acid, SyrA—syringic acid, SA—salicylic acid, Cat—catechin; ${ }^{*}$ values of correlation coefficients significant at $p<0.05,{ }^{* * *}$ values of correlation coefficients significant at $p<0.001$.

The analysis of the content of selected macro- and micronutrients (given per $100 \mathrm{~g}$ of fresh weight) revealed substantial diversity between the tested cultivars (Table 4). The 'Indomatrone' cultivar (C. maxima) revealed the highest accumulation (per 100 gf.w.) of most mineral nutrients, namely: K (469.8 mg), Mg (34.0 mg), S (49.3 mg), Na (6.82 mg), Fe (0.47 mg), and Mn (103.5 mg). At the same time, this cultivar contained relatively low level of B $(0.15 \mathrm{mg})$. Fruits of 'Sweet Dumpling' and 'Table Gold' of $C$. pepo contained significant amounts of $\mathrm{Mg}, \mathrm{P}, \mathrm{Na}$, and $\mathrm{Fe}$, while that of 'Halloween' (the same species) were particularly rich in calcium $(38.0 \mathrm{mg})$. 'Kogigu' (C. moschata) fruits were characterized 
by the highest accumulation of $\mathrm{Cu}(148.4 \mu \mathrm{g})$ as well as of K, P and S. The cultivars containing the lowest levels of mineral elements were 'Angle Hair' (C. ficifolia), 'Bambino' (C. maxima), and 'Miranda' (C. pepo). Interestingly however, in the fruits of 'Bambino' a relatively high content of Ca was measured (32.3 mg).

The highest concentration of total soluble sugars (expressed per $100 \mathrm{~g}$ of fresh weight) (Table 1 ) was determined in the fruits of 'Bambino' (7.89 g), 'Indomatrone' (7.34 g), and 'Chicago Warted Hubbard' $(7.34 \mathrm{~g})$ cultivars belonging to the C. maxima species. For the case of $C$. moschata, only 'Kogigu' tended to accumulate high amounts of sugars $(6.71 \mathrm{~g})$. The lowest levels were found for 'Sweet Dumpling' and 'Halloween' (C. pepo).

The content of amino acids also showed substantial differences between the analyzed Cucurbitaceae species and cultivars (Table 1). The highest values (in mg per 100 gf.w.) were noted for C. maxima cultivars 'Hokkaido' (109.5 mg) and 'Indomatrone' (71.3 mg), while the lowest for 'Musquée de Provence' (7.6 mg, C. moschata), 'Angel Hair' (13.0 mg, C. ficifolia) and 'Sweet Dumpling' (12.7 mg, C. pepo).

The analyzed cultivars were grouped according to their antioxidant and nutritional qualities upon hierarchical cluster analysis (HCA) (Figure 1). The main goal of this attempt was to classify the objects into clusters according to their similarity. Note however, that the employed method did not make it possible to obtain clusters homogenous for individual species of the Cucurbita genus.

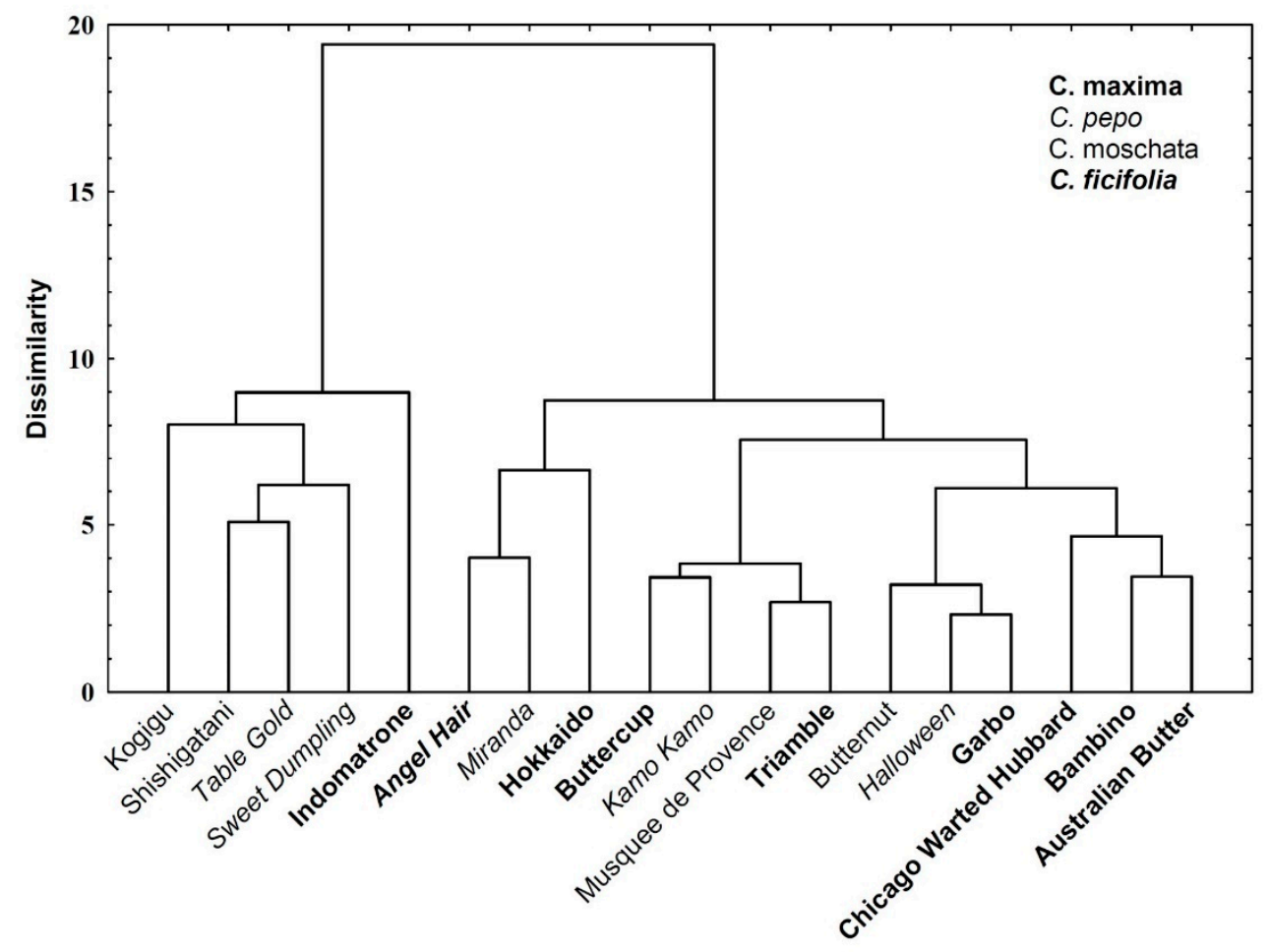

Figure 1. Dendrogram grouping 18 Cucurbita cultivars based on quality parameters including: the content of total and selected phenolic compounds, antioxidant capacity, the content of mineral elements, amino acids, and soluble sugars in the pulp. Dissimilarity was measured as Euclidean distance and the agglomeration was made with the use of Ward's method. 
Table 4. Content of selected macro- and micronutrients in the pulp of 18Cucurbita cultivars.

\begin{tabular}{|c|c|c|c|c|c|c|c|c|c|c|c|c|}
\hline \multirow[b]{2}{*}{ Species } & \multirow[b]{2}{*}{ Cultivar } & \multicolumn{9}{|c|}{ Content, $\mathrm{mg}^{100 \mathrm{~g}^{-1} \text { f.w. }}$} & \multicolumn{2}{|c|}{$\mu \mathrm{g} 100 \mathrm{~g}^{-1}$ f.w. } \\
\hline & & $\mathrm{Ca}$ & $\mathbf{K}$ & $\mathrm{Mg}$ & $\mathbf{P}$ & $\mathrm{S}$ & $\mathrm{Na}$ & B & $\mathrm{Fe}$ & $\mathrm{Zn}$ & $\mathrm{Cu}$ & Mn \\
\hline \multirow[t]{8}{*}{ C. maxima } & Australian Butter & $24.7 \pm 0,1^{\mathrm{ef}}$ & $218.8 \pm 3.9$ de & $14.2 \pm 0.5^{\text {efgh }}$ & $49.9 \pm 0.9^{\mathrm{e}}$ & $17.8 \pm 1.1^{\text {ef }}$ & $0.87 \pm 0.05^{b c}$ & $0.20 \pm 0.00 \mathrm{de}$ & $0.25 \pm 0.01^{c}$ & $0.37 \pm 0.02^{b}$ & $59.1 \pm 2.2$ ef & $36.0 \pm 1.7^{\mathrm{d}}$ \\
\hline & Bambino & $32.3 \pm 0.2 \mathrm{~g}$ & $144.9 \pm 6.9^{\mathrm{a}}$ & $7.1 \pm 0.9 \mathrm{ab}$ & $19.3 \pm 0.3^{b}$ & $15.6 \pm 0.6^{\mathrm{b}}$ & $0.41 \pm 0.05^{\mathrm{ab}}$ & $0.15 \pm 0.02 \mathrm{bc}$ & $0.24 \pm 0.02^{c}$ & $0.30 \pm 0.03^{b}$ & $53.8 \pm 2.0^{\mathrm{e}}$ & $33.9 \pm 2.2^{d}$ \\
\hline & Buttercup & $18.9 \pm 0.7 \mathrm{bc}$ & $303.6 \pm 5.2 \mathrm{~g}$ & $13.3 \pm 1.1$ def & $54.0 \pm 0.9^{f}$ & $26.4 \pm 0.2^{\mathrm{i}}$ & $2.22 \pm 0.17^{\mathrm{ij}}$ & $0.21 \pm 0.00 \mathrm{de}$ & $0.27 \pm 0.04^{\mathrm{cd}}$ & $0.56 \pm 0.00^{\mathrm{d}}$ & $86.2 \pm 3.7 \mathrm{~g}$ & $34.0 \pm 1.3^{\mathrm{d}}$ \\
\hline & $\begin{array}{c}\text { Chicago Warted } \\
\text { Hubbard }\end{array}$ & $24.5 \pm 0.8$ def & $324.8 \pm 14.2^{\mathrm{h}}$ & $7.3 \pm 0.7 \mathrm{ab}$ & $22.4 \pm 0.8^{c}$ & $19.3 \pm 0.1 \mathrm{~g}$ & $1.70 \pm 0.06^{\mathrm{gh}}$ & $0.18 \pm 0.01 \mathrm{~cd}$ & $0.19 \pm 0.00^{\mathrm{b}}$ & $0.20 \pm 0.01^{\mathrm{a}}$ & $22.9 \pm 1.9^{\mathrm{a}}$ & $22.0 \pm 1.4^{\mathrm{c}}$ \\
\hline & Garbo & $31.7 \pm 1.7^{\mathrm{g}}$ & $235.2 \pm 2.5^{\mathrm{e}}$ & $10.8 \pm 0.0^{c}$ & $23.2 \pm 1.7^{c}$ & $17.4 \pm 0.4 \mathrm{def}$ & $1.00 \pm 0.09$ cde & $0.24 \pm 0.01 \mathrm{e}^{\mathrm{e}}$ & $0.17 \pm 0.03^{b}$ & $0.19 \pm 0.01^{\mathrm{a}}$ & $25.4 \pm 1.5^{\mathrm{ab}}$ & $15.5 \pm 1.1^{\mathrm{ab}}$ \\
\hline & Hokkaido & $26.1 \pm 2.7$ ef & $323.3 \pm 0.4^{\mathrm{h}}$ & $7.4 \pm 0.5^{b}$ & $18.6 \pm 0.3^{b}$ & $15.1 \pm 0.4^{\mathrm{c}}$ & $0.20 \pm 0.02^{\mathrm{a}}$ & $0.21 \pm 0.02 \mathrm{de}$ & $0.15 \pm 0.02^{b}$ & $0.21 \pm 0.00^{\mathrm{a}}$ & $42.2 \pm 0.6^{\mathrm{cd}}$ & \\
\hline & Indomatrone & $32.2 \pm 1.2^{\mathrm{g}}$ & $469.8 \pm 10.8^{k}$ & $34.0 \pm 0.3^{\mathrm{i}}$ & $76.5 \pm 1.4^{\mathrm{h}}$ & $49.3 \pm 0.2^{\mathrm{k}}$ & $6.82 \pm 0.33^{\mathrm{m}}$ & $0.15 \pm 0.02 \mathrm{bc}$ & $0.47 \pm 0.00^{g}$ & $0.88 \pm 0.04^{f}$ & $122.8 \pm 7.7^{\mathrm{i}}$ & $103.5 \pm 3.1^{\mathrm{i}}$ \\
\hline & Triamble & $22.5 \pm 0.4^{\mathrm{de}}$ & $194.9 \pm 1.2^{\mathrm{c}}$ & $13.6 \pm 0.3^{\operatorname{defg}}$ & $54.7 \pm 0.1^{\mathrm{f}}$ & $18.7 \pm 0.1 \mathrm{fg}$ & $2.62 \pm 0.20^{\mathrm{jk}}$ & $0.11 \pm 0.00^{\mathrm{ab}}$ & $0.28 \pm 0.00^{\mathrm{cd}}$ & $0.52 \pm 0.02 \mathrm{~cd}$ & $68.9 \pm 1.6^{\mathrm{f}}$ & $38.6 \pm 0.5^{\mathrm{de}}$ \\
\hline \multirow[t]{5}{*}{ C. pepo } & Halloween & $38.0 \pm 2.3^{\mathrm{h}}$ & $291.0 \pm 3.4^{g}$ & $11.4 \pm 0.1^{\mathrm{cd}}$ & $23.8 \pm 1.3^{c}$ & $15.4 \pm 0.6^{c}$ & $1.51 \pm 0.02$ efg & $0.22 \pm 0.01 \mathrm{de}$ & $0.15 \pm 0.00^{\mathrm{b}}$ & $0.15 \pm 0.01^{\mathrm{a}}$ & $48.8 \pm 0.7 \mathrm{de}$ & $19.4 \pm 1.6^{\mathrm{bc}}$ \\
\hline & KamoKamo & $20.8 \pm 0.8^{\mathrm{cd}}$ & $259.4 \pm 1.9^{f}$ & $12.9 \pm 0.6$ cde & $24.0 \pm 0.1^{\mathrm{c}}$ & $17.2 \pm 0.2 \mathrm{de}$ & $2.40 \pm 0.27^{\mathrm{ij}}$ & $0.15 \pm 0.00 \mathrm{bc}$ & $0.31 \pm 0.01$ de & $0.35 \pm 0.01^{b}$ & $52.0 \pm 0.5 \mathrm{de}$ & $34.8 \pm 1.2^{\mathrm{d}}$ \\
\hline & Miranda & $17.8 \pm 1.2 \mathrm{bc}$ & $163.7 \pm 8.8^{b}$ & $5.1 \pm 0.8^{\mathrm{a}}$ & $14.1 \pm 1.1^{\mathrm{a}}$ & $9.0 \pm 0.1^{b}$ & $1.41 \pm 0.12 \operatorname{defg}$ & $0.14 \pm 0.01 \mathrm{abc}$ & $0.14 \pm 0.00^{\mathrm{b}}$ & $0.17 \pm 0.01^{\mathrm{a}}$ & $34.9 \pm 2.0 \mathrm{bc}$ & $11.4 \pm 0.7^{a}$ \\
\hline & Sweet Dumpling & $16.6 \pm 1.7^{b}$ & $272.9 \pm 3.5^{f}$ & $34.6 \pm 1.0^{\mathrm{i}}$ & $110.6 \pm 0.8^{j}$ & $29.3 \pm 0.8^{j}$ & $3.08 \pm 0.03 \mathrm{k}$ & $0.23 \pm 0.00^{\mathrm{e}}$ & $0.41 \pm 0.02 \mathrm{f}$ & $1.23 \pm 0.04 \mathrm{~g}$ & $101.2 \pm 3.3^{h}$ & $68.0 \pm 3.4 \mathrm{~g}$ \\
\hline & Table Gold & $24.8 \pm 0.6^{\text {ef }}$ & $390.7 \pm 0.7^{\mathrm{i}}$ & $15.9 \pm 1.8^{\mathrm{h}}$ & $88.9 \pm 0.5^{\mathrm{i}}$ & $22.2 \pm 0.8^{\mathrm{h}}$ & $3.56 \pm 0.17^{1}$ & $0.35 \pm 0.02^{\mathrm{f}}$ & $0.42 \pm 0.01^{\mathrm{f}}$ & $0.78 \pm 0.05^{\mathrm{e}}$ & $102.1 \pm 6.1^{\mathrm{h}}$ & $74.8 \pm 5.7^{\mathrm{h}}$ \\
\hline \multirow[t]{4}{*}{ C. moschata } & Butternut & $34.4 \pm 0.2^{g}$ & $212.3 \pm 8.4^{\mathrm{cd}}$ & $12.3 \pm 0.4^{\text {cde }}$ & $30.9 \pm 1.4^{\mathrm{d}}$ & $15.7 \pm 0.1^{\mathrm{c}}$ & $1.09 \pm 0.04$ cdef & $0.15 \pm 0.01 \mathrm{bc}$ & $0.16 \pm 0.01^{b}$ & $0.38 \pm 0.03^{b}$ & $59.8 \pm 1.7^{\text {ef }}$ & $32.5 \pm 0.9^{\mathrm{d}}$ \\
\hline & Kogigu & $9.9 \pm 0.5^{\mathrm{a}}$ & $434.7 \pm 6.8^{j}$ & $10.8 \pm 0.1^{\mathrm{c}}$ & $110.7 \pm 2.5^{j}$ & $29.2 \pm 0.3^{j}$ & $1.49 \pm 0.30^{\mathrm{efg}}$ & $0.14 \pm 0.01 \mathrm{bc}$ & $0.26 \pm 0.00^{\mathrm{cd}}$ & $0.46 \pm 0.04^{c}$ & $148.4 \pm 7.2^{j}$ & $43.3 \pm 0.7^{\mathrm{e}}$ \\
\hline & $\begin{array}{l}\text { Musquéede } \\
\text { Provence }\end{array}$ & $27.0 \pm 0.4^{\mathrm{f}}$ & $222.9 \pm 0.6 \mathrm{de}$ & $15.3 \pm 0.4^{\mathrm{fgh}}$ & $65.3 \pm 0.4^{\mathrm{g}}$ & $16.0 \pm 0.3^{\mathrm{cd}}$ & $1.53 \pm 0.27^{\mathrm{fg}}$ & $0.09 \pm 0.00^{\mathrm{a}}$ & $0.27 \pm 0.01^{\mathrm{cd}}$ & $0.35 \pm 0.00^{b}$ & $53.9 \pm 4.2^{\mathrm{e}}$ & $38.0 \pm 0.8$ de \\
\hline & Shishigatani & $23.6 \pm 0.3$ def & $327.0 \pm 4.9^{\mathrm{h}}$ & $15.7 \pm 0.4 \mathrm{gh}$ & $87.9 \pm 0.3^{\mathrm{i}}$ & $21.9 \pm 0.3^{\mathrm{h}}$ & $2.09 \pm 0.09$ hi & $0.21 \pm 0.03 \mathrm{de}$ & $0.33 \pm 0.01 \mathrm{e}^{\mathrm{e}}$ & $0.55 \pm 0.03^{\mathrm{d}}$ & $60.5 \pm 3.7^{\text {ef }}$ & $60.9 \pm 1.5^{\mathrm{f}}$ \\
\hline C. ficifolia & Angel Hair & $23.5 \pm 0.7$ def & $137.5 \pm 4.8^{\mathrm{a}}$ & $5.9 \pm 0.2^{\mathrm{ab}}$ & $12.9 \pm 0.1^{\mathrm{a}}$ & $7.5 \pm 0.2^{\mathrm{a}}$ & $0.97 \pm 0.06^{\mathrm{cd}}$ & $0.11 \pm 0.01^{\mathrm{ab}}$ & $0.08 \pm 0.00^{\mathrm{a}}$ & $0.13 \pm 0.01^{a}$ & $15.4 \pm 0.8^{\mathrm{a}}$ & $34.6 \pm 0.6^{d}$ \\
\hline
\end{tabular}

The values are given as means \pm standard errors, followed by the letters a-m (in superscripts) to indicate statistical significance. The values marked with the same letters in one column are

not statistically different at the $p<0.05 ; n=3$; n.a., not analyzed. 
In the further step, the principal component analysis (PCA) was performed to identify the main sources of variability between the analyzed cultivars with respect to their nutritional qualities (Figure 2). The PCA analysis was applied to mean values and allowed extraction of five principal components with eigenvalues above 1 that accounted for $84.39 \%$ of the variability of 21 tested parameters (Table 5). The first principal component (PC1) accounted for $39.12 \%$ of the total variance and integrated the content of most mineral elements ( $\mathrm{Cu}, \mathrm{Fe}, \mathrm{K}, \mathrm{Mg}, \mathrm{Mn}, \mathrm{Na}, \mathrm{P}, \mathrm{S}, \mathrm{Zn}$ ) as well as the total phenolics (Table 6). PC2 (14.26\% of total variance) was mainly negatively correlated with the content of salicylic acid. The third principal component (PC3) explained $13.36 \%$ of the variance and was positively correlated with the content of amino acids as well as the antioxidant activity as measured by the FRAP method. In turn, PC4 was moderately negatively correlated with the antioxidant capacity measured with all three methods and positively correlated with the content of syringic acid, yet the loading factor did not exceed $|0.7|$. Finally, PC5 was negatively related to the content of B.

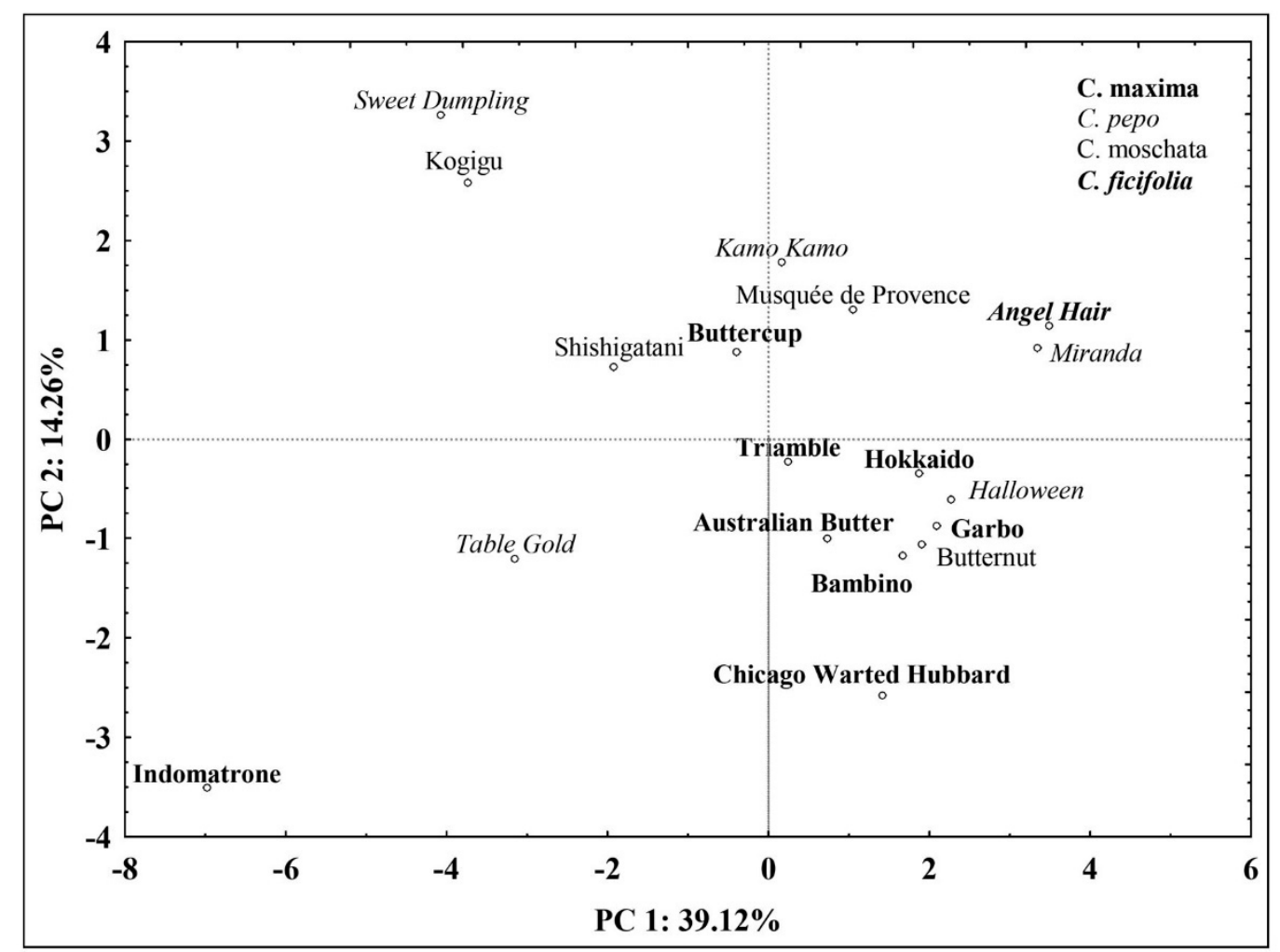

Figure 2. PCA score plot for Cucurbita cultivars, PC 1-principal component 1, PC 2-principal component 2.

Table 5. Eigenvalues, percentage of variance and cumulated percentage of variance for the first five principal components obtained in the PCA.

\begin{tabular}{cccc}
\hline & Eigenvalue & \% Variance & Cumulated \% Variance \\
\hline PC1 & 8.21 & 39.12 & 39.12 \\
PC2 & 2.99 & 14.26 & 53.38 \\
PC3 & 2.81 & 13.36 & 66.74 \\
PC4 & 2.34 & 11.12 & 77.86 \\
PC5 & 1.37 & 6.53 & 84.39 \\
\hline
\end{tabular}


Table 6. Factor loadings of analyzed variables for the first five principal components.

\begin{tabular}{cccccc}
\hline Variable & PC1 & PC2 & PC3 & PC4 & PC5 \\
\hline Protocatechuic acid & -0.227 & 0.299 & 0.442 & 0.466 & -0.466 \\
p-hydroxybenzoic acid & -0.374 & -0.470 & 0.292 & 0.384 & 0.311 \\
Salicylic acid & -0.325 & $\mathbf{- 0 . 8 1 0}$ & -0.185 & 0.082 & -0.137 \\
Syringic acid & $-\mathbf{0 . 5 5 7}$ & 0.491 & 0.196 & 0.536 & 0.069 \\
B & -0.273 & -0.177 & -0.226 & -0.123 & $-\mathbf{0 . 8 3 7}$ \\
Ca & 0.271 & -0.689 & -0.283 & -0.139 & -0.057 \\
Cu & $\mathbf{- 0 . 8 7 9}$ & 0.157 & 0.025 & 0.242 & -0.062 \\
Fe & $\mathbf{- 0 . 9 0 3}$ & -0.036 & -0.232 & -0.161 & 0.017 \\
K & $\mathbf{- 0 . 7 8 6}$ & -0.193 & 0.238 & 0.179 & -0.325 \\
Mg & $\mathbf{- 0 . 8 1 7}$ & 0.014 & -0.296 & -0.335 & 0.135 \\
Mn & $\mathbf{- 0 . 8 9 8}$ & -0.130 & -0.138 & -0.222 & 0.11 \\
Na & $\mathbf{- 0 . 8 1 0}$ & -0.261 & -0.248 & -0.174 & 0.178 \\
P & $\mathbf{- 0 . 8 5 4}$ & 0.326 & -0.110 & 0.133 & -0.098 \\
S & $\mathbf{- 0 . 9 2 2}$ & -0.212 & 0.024 & 0.019 & 0.131 \\
Zn & $\mathbf{- 0 . 8 5 9}$ & 0.157 & -0.262 & -0.269 & 0.008 \\
Total phenols & $\mathbf{- 0 . 7 4 0}$ & 0.374 & 0.168 & 0.262 & 0.177 \\
FRAP & -0.145 & -0.048 & $\mathbf{0 . 7 1 6}$ & -0.651 & -0.052 \\
CUPRAC & -0.452 & -0.016 & 0.573 & -0.571 & -0.037 \\
DPPH & 0.102 & 0.573 & 0.381 & -0.599 & 0.023 \\
Soluble sugars & -0.077 & -0.501 & 0.631 & 0.253 & 0.272 \\
Amino acids & -0.127 & -0.486 & $\mathbf{0 . 7 4 1}$ & 0.037 & -0.149 \\
\hline
\end{tabular}

Factor loading $\geq|0.70|$ are marked in bold.

A scatter plot of the score values attributed to the genotypes projected to PC1 and PC2 failed to provide a clear distinction between the analyzed Cucurbita species based on the analyzed nutritional and antioxidant parameters. It was mainly because relatively small percentage of variance $(53.38 \%)$ was explained by the first two principal components (Figure 2). However, most of the tested C. maxima cultivars grouped closely with the exception of 'Indomatrone'. The significant distance of that cultivar from the origin and from other tested genotypes is mainly related to significant accumulation of the analyzed mineral elements, as well as of salicylic and syringic acids as described above. These results indicate high intraspecies variability in Cucurbita genus regarding the accumulation of health-promoting compounds and the antioxidant capacity.

\section{Discussion}

Polyphenols are plant secondary metabolites with high antioxidant capacity. Their activity is determined by direct reaction with free radicals, scavenging of free radicals and singlet oxygen, reactivity as hydrogen- or electron-donating agents, capability of reacting with other antioxidants, ability to produce new generation of antioxidant-derived radicals, and by the potential of chelating transition metals [44,45].Phenolic compounds occur widely in fruits, vegetables, herbs, and beverages [46-49]. From among the tested Cucurbita pulps, the Japanese 'Kogigu' (C. mochata) cultivar was extraordinary in terms of the total phenolic content; it contained the highest amount of these compounds (70.8 CAE $100 \mathrm{~g}^{-1}$ f.w.). For syringic acid, the 'Kogigu' fruit accumulated this compound three times as much as the second in order 'Shishigatani' of the same species. In addition, 'Kogigu' contained the most protocatechuic acid and the flavonoids: catechin and kaempferol. The other cultivar with the elevated content of several phenolic acids was C. maxima cv. 'Chicago Warted Hubbard'; its fruits revealed the highest concentrations of $p$-hydroxybenzoic, and $p$-coumaric acids among all the tested fruits, and were the second to accumulate ferulic and caffeic acids.

Biological activity of $p$-coumaric, caffeic, and ferulic acids are quite similar. They are synthesized via the shikimate pathway where $p$-coumaric acid is converted into caffeic acid by hydroxylation, whereas the latter one forms ferulic acid upon methylation [50]. The antioxidant potential of these compounds depends primarily on the number of hydroxyl and methoxy groups attached to the phenyl 
ring [51]. Antioxidant capacities of a series of phenolic acids and flavonoids were earlier measured by Rice-Evans et al. [44]. Based on their work, the antioxidant power of phenolic acids identified for Cucurbita fruits in our study can be arranged in the following order: $p$-coumaric $>$ ferulic $>$ syringic $>$ caffeic $>$ protocatechuic $>$ salicylic $>p$-hydroxybenzoic acids. In turn, according to Kikuzaki et al. [52], the radical DPPH scavenging activity decreased in the order: caffeic acid $>$ ferulic acid $>p$-coumaric acid. In our study, the contents of $p$-coumaric and caffeic acids in all samples were relatively low, while the contents of ferulic acid varied significantly upon the tested cultivar. The fruits of 'Kogigu' (C. moschata), 'Garbo', and 'Chicago Warted Hubbard' (C. maxima) contained the highest amounts of ferulic acid. Cucurbits are known as rich sources of this polyphenol compared to other fruits and vegetables; only some leguminous vegetables and tomatoes were shown to accumulate it to a greater extent [53]. Ferulic acid is known to exert anti-angiogenic and anti-tumor effects by affecting the activity of vascular endothelial growth factor (VEGF), platelet derived growth factor (PDGF) and hypoxia-inducible factor 1 (HIF-1) [54]. It can also inhibit skin photo-aging and therefore has been used as a component of cosmetic preparations [53]. Salicylic acid was also detected in the examined Cucurbita fruits. Notwithstanding its moderate antioxidant capacity, this compound is widely known to reduce the risk of myocardial infarction and ischemic stroke. Although its content in cucurbits is much lower than e.g., in raspberries, the pumpkin pulp can still provide continuous supplementation in this phenolic compound due to the long storage time and the substantially larger resources available for food processing.

Two flavonoids: catechin and kaempferol were detected in most fruit pulps. Flavonoids are efficient antioxidants with well-pronounced health-beneficial properties. They can protect against oxidative-stress based diseases and are able to modulate enzyme activities as well as interactions with specific receptors. Their comprehensive mode of action includes quenching of free radicals, chelating metals, suppressing the enzymes associated with free radical generation, and stimulation of internal antioxidant enzymes [55]. Protective action of flavonoids against cardiovascular diseases was confirmed, which was based-among other mechanisms—on decreasing the oxidation rate of low-density lipoproteins [56]. Kaempferol has recently focused special interest and is currently considered as a potential cancer treatment agent because of its strong capacity to reduce the oxidative stress $[57,58]$. Note that, although in the commonly consumed vegetables (e.g., onions) and in several herbs, kaempferol may occur in concentrations much higher than in pumpkin, the size of a single serving of a pumpkin dish is significantly larger and therefore may provide considerable and biologically-significant quantities of this health-beneficial compound.

The obtained results indicate that Cucurbita vegetables contain relatively low amounts of phenolics, especially when compared to richer sources such as berries or grapes [46,59]. However, the level of phenolic compounds in selected Cucurbita cultivars was comparable to those noted for potatoes (36.9-52.7 mg $100 \mathrm{~g}^{-1}$ f.w.) [60] and carrots, with the exception of purple cultivars (24.2-40.4 mg $100 \mathrm{~g}^{-1}$ f.w.) [61]. Additionally, the pulp of selected Cucurbita cultivars, such as 'Indomatrone' or 'Sweet Dumpling' can be considered as a richer source of essential mineral nutrients such as: $\mathrm{Cu}, \mathrm{Zn}$, and $\mathrm{Mg}$ as compared to the mentioned two other crop species [62,63].

It should be emphasized that the abundance of phenolic compounds does not necessarily imply high total antioxidant potential of any biological sample. The antioxidant properties of Cucurbita may also result from the presence of carotenoids which are usually assumed to play a predominant role in this respect. However, the pumpkin pulp was also found to be rich in vitamins $C$ and $E[64,65]$ as well as in carbohydrates, which all might add to the resultant activity. The abovementioned facts imply that it is very difficult to estimate the total antioxidant power only based on the content of particular bioactive compounds. This conclusion gave reasons to launch direct measurements of antioxidant (CUPRAC, FRAP) and antiradical (DPPH) capacities of pumpkin flesh extracts. For the case of Cucurbitaceae, it is a novel approach, first applied in our pilot work [66], and follows that of the most recent study of Kulczyński et al. [67]. Similarly to our strategy, these authors have employed several independent methods to evaluate antioxidant potential of 14 C. maxima cultivars. Their optimized extraction method 
(with $80 \%$ methanol/water) was very close to the one elaborated for this study. Here, apart from C. maxima (out of the eight cultivars, only 'Hokkaido' and 'Buttercup' were examined in both studies) the testing included also cultivars belonging to other species (C. pepo, C. moschata, C. ficifolia).

The fruit of 'Hokkaido' exhibited the maximum antioxidant potential as revealed by the assays CUPRAC, FRAP, and DPPH which are the most sensitive methods towards phenolic compounds [59]. Positive correlations between TPCs and the antioxidant capacities were also shown in this work (Table 3). This cultivar is famous for its intensive orange-colored pulp, which results from the high concentration of carotenoids, mainly $\beta$-carotene $[33,34]$ whose antioxidant activity is based on singlet oxygen quenching and ability to trap peroxyl radicals [68]. Taking into account the content of phenolic compounds (Table 2), it is thus justified that both carotenoids and phenolics contributed to the resultant exceptional activity. It should be noted here that in the complementary study [67] 'Hokkaido' also ranked high among the other tested C. maxima cultivars in terms of antioxidative/antiradical activity. The fruits of 'Indomatrone' accumulated the highest amounts of total phenols and, expectedly, they revealed the highest antioxidant capacities as measured by FRAP and CUPRAC assays. At the same time, their antiradical capacity determined upon the DPPH method was the lowest of all the tested fruits. Possibly, the pulp of 'Indomatrone' contained some fraction of other polyphenols with a different mechanism of action than the typical polyphenols of Cucurbita. Note that, in fact, only the DPPH assay allowed for direct measurement of antiradical capacity since DPPH itself is a free radical. Also, high content of soluble sugars as measured for this cultivar should be considered as a reliable explanation of the observed facts. It was demonstrated that the mono- and disaccharides, especially fructose, interfered with the Folin-Ciocalteu reagent, leading to overestimation of the final results [69]. Hence, the antioxidants of 'Indomatrone' fruits require a more detailed analysis.

Many fruits and leaves rich in lutein are considered helpful in treatment of aged-related macular degeneration (AMD) and cataracts as the loss of these pigments in the retina is observed during the AMD development. However, supplementation with sole lutein or with lutein and zeaxanthin had little or no effect on progression of AMD and subsequent AMD vision loss, while additional zinc combined with the antioxidant vitamins ( $C$ and E) slowed down progression of this disease [70]. C. pepo 'Sweet Dumpling' and C. maxima 'Indomatrone' were the cultivars with the highestZn content in their

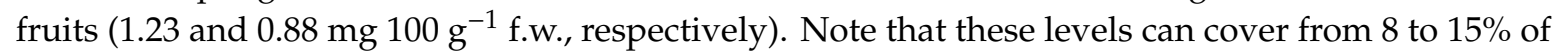
zinc Recommended Daily Allowance (RDA) for people over 70 years old (Table S1) [71,72]. The two

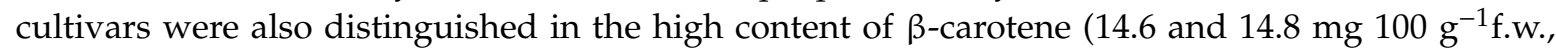
respectively) which is a precursor of zeaxanthin. Since the Cucurbita fruits contain pronounced amounts of vitamin $E[21,64,65]$ as well as these xanthophylls $[64,65]$, they seem to have the necessary qualities to slow down the development of the retinal diseases.

Trace elements in human nutrition are required for the proper activity of antioxidant enzymes crucial for efficient defense against the excess of reactive oxygen species (ROS): $\mathrm{Cu}, \mathrm{Mn}$, and $\mathrm{Zn}$ for superoxide dismutase (SOD), Fe for catalase (CAT), and Se in selenocysteine for glutathione peroxidase (GPx). Our data show that the tested Cucurbita fruits contained significant amounts of $\mathrm{Zn}$ and $\mathrm{Cu}$ as referred to RDA values for seniors (Table S1) [71,72]. The highest $\mathrm{Cu}$ content was noticed for 'Kogigu' of C. moschata; its $100 \mathrm{~g}$ serving allows for $16.5 \%$ supply of daily demand for this microelement. It was confirmed that $\mathrm{Zn}$ supplementation effectively reduced oxidative stress and generation of inflammatory cytokines such as TNF- $\alpha$ and IL-1 $\beta$ in elderly individuals [73]. Furthermore, the relationship between $\mathrm{Cu}$ to $\mathrm{Zn}$ ratio $(\mathrm{CZr})$ and mortality rates gave reasons to suggest that $\mathrm{CZr}$ is a biomarker of aging.

The presented research work on fruits of 18 Cucurbita cultivars enabled to compare their antioxidant properties and confirmed the great diversity found for different objects. This observation is similar to that reported by other authors for many other examined cultivars $[64,65,67]$. Such variability should not be considered surprising, taking into account that pumpkin is one of the first domesticated plants and has been grown worldwide for several hundred years thus giving farmers enough time to obtain and introduce cultivars with unique characteristics. The fruits subjected to our study differed profoundly in terms of the content of phytochemicals as well as their antioxidant potential and 
antiradical capacity. Statistical analyses show that these differences were associated with distinct characteristics of a particular cultivar, and could not be generalized as specific to individual species. The greatest variations in phenolic content were reported for protocatechuic, syringic, and salicylic acids. Moreover, not all the tested phenols were detected in all the cultivars. Unfortunately, the majority of other available studies on Cucurbita do not bring results as dependent on examination of several variant cultivars, which leaves little space for making comparisons.

Generally, it is difficult to compare the data on the content of antioxidants in the fruits of different cultivars. The resultant information is influenced by genetic differences and affected by environmental conditions, degree of maturity at harvest, and storage conditions [74]. Note that Cucurbita fruits can often be used when they are not yet fully ripe. C. ficifolia, C. maxima, and C. moschata are known as winter squashes that can be stored for months; however, among the C. pepo cultivars there are several ones whose fruits can be consumed only as summer squashes. Fruit maturation involves a series of complex reactions that lead to changes in plant phytochemistry. Two different phenomena of phenolic compound changes were observed during maturation: a gradual decrease $[75,76]$ or an increase at the end of the process [77-79]. Furthermore, concentration of antioxidants varied within the plant organs and tissues [80,81].

In many research articles, it is stressed that high reactivity and great structural and molecular diversity of phenolics makes them very difficult to study, as evidenced by ambiguous and sometimes contradictory results [82]. Divergent sample preparation procedures and the lack of measurement standardization are additional reasons for unsatisfactory data comparability. Therefore, we emphasize the need for methodological unification of antioxidant capacity tests based on standardized extraction procedures, especially regarding groups of related plants with similar chemical characteristics. We also point to the fact that extensive studies on beneficial action of phenolic compounds on human health have only started a few years ago [27]. It is already known that dietary polyphenols undergo several transformations in the body (i.e., deglycosylation, oxidation, dehydroxylation, demethylation), and their bioavailability may vary significantly [82], usually remaining relatively low [83]. Therefore, the elevated and potentially toxic concentrations of polyphenols, as reported in several works, can only be reached when these compounds are applied as concentrated supplements or therapeutic medicines [28]. Unfortunately, the data on the bioavailability of phenolics and other nutrients of Cucurbita fruits are still scarce. Studies on the content of anti-nutrients such as tannins, oxalates, saponins, phytates, alkaloids, and cyanide in Cucurbita pulp, demonstrate low or acceptable amounts of these substances as referred to the daily intake [35,84-86]. Considering the above, the application of polyphenols obtained from the natural sources such as cucurbits appear to be the most favorable and the safest way of supplementation.

As regards directions of future studies of natural antioxidative agents, the research should focus on characterizing antioxidant intake mechanisms and correlating them with biological availability. This approach seems to be necessary to complement current efforts made to elucidate the impact of antioxidants on oxidative stress responses. Also it is noteworthy that the antioxidant capacity analyses of this study were performed in vitro and, although the standardized methods were employed, the next-stage complementary research is required involving the in vivo testing with free radicals physiologically present in the human body. Moreover, appropriate clinical trials are necessary to evaluate real dietary potential of pumpkin fruits towards the elderly population.

To conclude, the results obtained from a systematic research on fruits of 18 Cucurbita cultivars bring valuable information on the unique properties of Cucurbita and reveal considerable diversity of both the content of bioactive compounds and antioxidant/antiradical capacities. The detected phenolic compounds, $\beta$-carotene, $\mathrm{Zn}$, and $\mathrm{Cu}$ could be useful in the nutrition of elderly people suffering from chronic diseases. It is finally emphasized, however, that even if the concentration of a particular nutrient or antioxidant is lower than in other plant material (medicinal plants, herbs, other vegetables), the Cucurbita fruits have the advantage of being easily digestible and possessing low 
glycemic index, which allows for their supply in high amounts and serving in many variant ways after appropriate processing.

\section{Materials and Methods}

\subsection{Plant Material}

All studied fruits were harvested in Wawrzeńczyce $\left(50^{\circ} 06^{\prime} \mathrm{N} 20^{\circ} 19^{\prime} \mathrm{E}\right.$; southern Poland). Eight cultivars were of Cucurbita maxima Duchesne species ('Australian butter', 'Bambino','Buttercup','Chicago Warted Hubbard', 'Garbo', 'Hokkaido', 'Indomatrone', and 'Triamble'), five cultivars of Cucurbita pepo L. ('Halloween', 'KamoKamo', 'Miranda', 'Sweet Dumpling', and 'Table Gold'), four cultivars of Cucurbita moschata Duchesne ('Butternut', 'Kogigu', 'Musquée de Provence', and 'Shishigatani') and one ('Angel Hair') was a cultivar of a fig-leaf gourd (Cucurbita ficifolia Bouché). The fruits were fully ripe and were examined immediately after harvesting. Upon collecting, the fruit material was fragmented into small pieces, frozen at $-25^{\circ} \mathrm{C}$ and then freeze-dried $(0.37 \mathrm{mBa})$ for $48 \mathrm{~h}$. The samples were stored at $-25^{\circ} \mathrm{C}$ in the dark.

\subsection{Sample Preparation}

The extracts were prepared by grinding $0.75 \mathrm{~g}$ of the freeze-dried material in a mortar with $80 \%$ methanol (Sigma-Aldrich, St. Louis, MO, USA) applied in several portions. Each homogenate was then filtered through a sintered glass funnel to a volumetric flask and filled up to the total volume of $25 \mathrm{~mL}$. The extraction procedure was carried out at $22^{\circ} \mathrm{C}$ under limited lighting. Three fruit extracts were made for each cultivar. The extracts were stored in the dark at $-25^{\circ} \mathrm{C}$ for a maximum of two weeks.

\subsection{Total Phenolic Content (TPC)}

The content of phenolic compounds in the extracts was determined based on the reaction with the Folin-Ciocalteu reagent [87]. The extract $(0.25 \mathrm{~mL})$ was mixed with $0.25 \mathrm{~mL}$ of $25 \% \mathrm{Na}_{2} \mathrm{CO}_{3}, 0.125 \mathrm{~mL}$ of the Folin-Ciocalteu reagent (Sigma-Aldrich, diluted twice with water prior to the analysis), $2.25 \mathrm{~mL}$ of water, and then incubated for $15 \mathrm{~min}$. The absorbance was measured at $760 \mathrm{~nm}$ (JASCO V-530 UV-Vis spectrophotometer). The final results were expressed as $\mathrm{mg}$ of chlorogenic acid (Sigma-Aldrich) per $100 \mathrm{~g}$ of fresh weight (chlorogenic acid equivalents, CAE $100 \mathrm{~g}^{-1}$ ).

\subsection{Antioxidant Capacity-A FRAP Assay}

The FRAP (ferric reducing antioxidant power) assay is based on the reduction of ferric-tripyridyl-s-triazine $\left(\mathrm{Fe}^{+3}-\mathrm{TPTZ}\right)$ complex to its ferrous derivative $\left(\mathrm{Fe}^{2+}\right)$ [88]. The FRAP working solution was prepared fresh by mixing $300 \mathrm{mM}$ acetate buffer (pH 3.6), $10 \mathrm{mM}$ TPTZ (Sigma-Aldrich) in $96 \%$ ethanol, and $20 \mathrm{mM} \mathrm{FeCl}_{3}$ (10:1:1, v:v:v). Then, $3 \mathrm{~mL}$ of FRAP working solution were mixed with $0.1 \mathrm{~mL}$ of fruit extract and $0.3 \mathrm{~mL}$ of water. The absorbance was measured at $595 \mathrm{~nm}$ after $30 \mathrm{~min}$. The results were expressed as $\mu \mathrm{mol}$ Trolox (6-hydroxy-2,5,7,8-tetramethylchroman-2-carboxylic acid; Sigma-Aldrich) per $100 \mathrm{~g}$ of fresh weight (Trolox equivalents, TE $100 \mathrm{~g}^{-1}$ ).

\subsection{Antioxidant Capacity-A CUPRAC Assay}

The CUPRAC (cupric ion reducing antioxidant capacity) assay is based on the measurement of utilization of copper (II)-neocuproine as chromogenic oxidizing agent [89-91]. Briefly, $1 \mathrm{~mL}$ of $10 \mathrm{mM}$ $\mathrm{CuCl}_{2}, 1 \mathrm{~mL}$ of $7.5 \mathrm{~m}$ Mneocuproine (Sigma-Aldrich) in $96 \%$ ethanol and $1 \mathrm{~mL}$ of $1 \mathrm{M} \mathrm{NH}_{4} \mathrm{Ac}$ buffer, $\mathrm{pH} 7.0$, were mixed with $0.3 \mathrm{~mL}$ of the fruit extract and $0.8 \mathrm{~mL}$ of water. The absorbance was measured at $450 \mathrm{~nm}$ after $30 \mathrm{~min}$. The results were expressed as $\mu \mathrm{mol}$ Trolox (Sigma-Aldrich) per $100 \mathrm{~g}$ of fresh weight (TE $\left.100 \mathrm{~g}^{-1}\right)$. 


\subsection{Radical Scavenging Capacity (RSC)-A DPPHAssay}

The radical scavenging capacity of extracts was tested following the reduction of a synthetic, stable free radical 2,2-diphenyl-1-picrylhydrazyl (DPPH•). The colorimetric method enables to measure absorbance changes of DPPH solution at $517 \mathrm{~nm}$ as a result of antioxidant activity of the sample [92]. Briefly, $2.8 \mathrm{~mL}$ of $0.1 \mathrm{mM}$ DPPH (Sigma-Aldrich) solution in 96\% ethanol was mixed with $0.2 \mathrm{~mL}$ of the extract. The DPPH absorbance was detected after $30 \mathrm{~min}$. The RSC results were expressed as $\mu \mathrm{mol}$ Trolox (Sigma-Aldrich) per $100 \mathrm{~g}$ of fresh weight (TE $100 \mathrm{~g}^{-1}$ ).

\subsection{Identification of Phenolic Compounds with HPLC}

In order to identify phenolic compounds in fruit extracts, a high-performance liquid chromatography (HPLC) method was used (Shimadzu LC-10AS chromatograph equipped with a C18 RP column and SPD-10AV UV-Vis detector). Signal detection was set at the wavelengths of 325 and $265 \mathrm{~nm}$. Chromatographic separation was carried out at $33 \pm 1^{\circ} \mathrm{C}$. using the following solvents: (A) water (Sigma-Aldrich) with acetic acid (0.1\%), (B) methanol (Sigma-Aldrich, ultra pure) with acetic acid (0.1\%) and applying the gradient: 90\% A, 10\% B for $20 \mathrm{~min} ; 75 \% \mathrm{~A}, 25 \%$ B for $30 \mathrm{~min} ; 65 \% \mathrm{~A}$, $35 \%$ B for $40 \mathrm{~min} ; 55 \%$ A, 54\% B for $50 \mathrm{~min} ; 50 \%$ A, 50\% B for $60 \mathrm{~min} ; 30 \%$ A, $70 \%$ B for $62 \mathrm{~min} ; 100 \%$ B to $80 \mathrm{~min} ; 80 \% \mathrm{~A}, 10 \% \mathrm{~B}$ up to $85 \mathrm{~min}$. The flow rate was $1 \mathrm{~mL} / \mathrm{min}$. The identification of phenolics was based on the retention times of chlorogenic, caffeic, $p$-hydroxy-benzoic acid, $p$-coumaric, ferulic, protocatechuic, syringic acids (Sigma-Aldrich), salicylic acid (LGC Standards) as well as (+)-catechin (LGC Standards) andkaempferol (Sigma-Aldrich).

\subsection{Identification of $\beta$-Carotene with HPLC}

Identification of $\beta$-carotene was carried out employing the high performance liquid chromatography method (Shimadzu LC-20AD chromatograph with Develosil RPAQEOUS-AR C30 column and Shimadzu SPDM-20A-DAD photodiode-array detector). The signal detection was set at the wavelengths of 452 and $444 \mathrm{~nm}$. The separation was carried out at $25 \pm 1{ }^{\circ} \mathrm{C}$ with the solvents: (A) $1 \%$ water in methanol (Sigma-Aldrich, ultra pure), (B) methanol, (C) 10\% n-hexane (Sigma-Aldrich, ultra pure) in acetonitrile (Sigma-Aldrich, ultra pure), and applying the following gradient: starting with the initial ratio of $95 \%$ A, 5\% B to 30\% A, 70\% B up to $5 \mathrm{~min}$; then $100 \%$ B for $10 \mathrm{~min}$; $100 \%$ C up to $25 \mathrm{~min}$, then maintaining this proportion up to $60 \mathrm{~min} ; 100 \% \mathrm{~B}$ up to $62 \mathrm{~min} ; 95 \% \mathrm{~A}, 5 \% \mathrm{~B}$ up to $63 \mathrm{~min}$ and maintaining this proportion up to $70 \mathrm{~min}$ separation. The flow rate was $1 \mathrm{~mL} / \mathrm{min}$. The identification of $\beta$-carotene was based on the retention time of a standard compound (Sigma-Aldrich) and confirmed by analysis of absorption spectra. $\beta$-carotene was determined for selected fruits only, namely for these cultivars that had not earlier been tested and documented in the literature data.

\subsection{Determination of the Content of Selected Macro- and Microelements, Free Amino Acids, and Soluble Sugars}

The content of $\mathrm{Ca}, \mathrm{K}, \mathrm{Mg}, \mathrm{P}, \mathrm{S}, \mathrm{B}, \mathrm{Cu}, \mathrm{Fe}, \mathrm{Mn}, \mathrm{Na}$, and $\mathrm{Zn}$ in the pulp of Cucurbita cultivars was measured with an ICP-OES technique. Samples of $0.5 \mathrm{~g}$ of freeze-dried pulp were subjected to microwave digestion in 65\% super-pure nitric acid with the use of CEM MARS-5 Xpress (CEM World Headquarters, Matthews) microwave digestion system [93]. Determination of soluble sugars and free amino acids was conducted in methanolic extracts of the freeze-dried pulp. The content of soluble sugars was measured with the anthrone method using glucose as a standard [94]. Free amino acids were analyzed spectrophotometrically after the reaction of methanolic extracts with ninhydrin using glycine as a standard compound [95]. The obtained results were calculated per 100 gf.w.

All other chemicals such as salts and buffer constituents were of analytical grade, purchased from Chempur/POCh (Poland). All standards and solutions were prepared with p.a. chemicals and deionized water daily prior to the measurements. During analyses of antioxidant compounds, the room was partially darkened and a stable room temperature of $22{ }^{\circ} \mathrm{C}$ provided. The analytical spectroscopic system was maintained according to the GLP rules [96]. 


\subsection{Statistical Analysis}

All analyses were performed in triplicates. One-way analysis of variance (ANOVA) was applied to compare differences between mean values and the means were compared by a Duncan's test at $\alpha=0.05$. Calculations of Pearson's correlation coefficients for selected parameters were performed. To overview the correlations between quality parameters as well as the relationships between Cucurbitaceae cultivars and their chemical characteristics, a PCA analysis was performed on the correlation matrix obtained for the standardized data set [97]. The hierarchical cluster analysis (HCA) was carried out based on the Euclidean distance and Ward's method. All statistical analyses were done with the use of Statistica 13 software (StatSoft) [98].

Supplementary Materials: The following are available online. Contain exemplary HPLC chromatograms of phenolic compounds identified in fruit extracts of four Cucurbita species; (Figure S1) and a table (Table S1) which depicts the coverage of the requirements for selected macro- and micronutrients by the consumption of $100 \mathrm{~g}$ servings of fresh pumpkin based on the RDA and AI values set for adults $>70$ years old [71,72].

Author Contributions: Conceptualization, A.K.-G., I.L.-S., and P.K.; Methodology, M.K. and I.L.-S..; Validation, M.K. and I.L.-S.; Formal analysis, I.L.-S. and A.K.-G.; Investigation, M.K., I.L.-S., and A.K.-G.; Resources, A.K.-G. and I.L.-S.; Data curation, I.L.-S.; Writing—original draft preparation, A.K.-G., I.L.-S., and P.K.; Writing-review and editing, A.K.-G., I.L.-S., and P.K.; Visualization, I.L.-S. and A.K.-G.; Funding acquisition, P.K. and A.K.-G. All authors have read and agreed to the published version of the manuscript.

Funding: The research at the University of Agriculture in Krakow was subvented by the Polish Ministry of Science and Higher Education in 2020.

Acknowledgments: We appreciate Agnieszka Pycia, a student of University of Agriculture in Krakow, Poland for her technical assistance during extractions and the part of spectrophotometric measurements.

Conflicts of Interest: The authors declare no conflict of interest.

\section{References}

1. Smith, B.D. The Initial Domestication of Cucurbita pepo in the Americas 10,000 Years Ago. Science 1997, 276, 932-934. [CrossRef]

2. Bisognin, D.A. Origin and evolution of cultivated cultivars. Ciência Rural 2002, 32, 715-732. [CrossRef]

3. Paris, H.S. Historical records, origins, and development of the edible cultivar groups of Cucurbita pepo (Cucurbitaceae). Econ. Bot. 1989, 43, 423-443. [CrossRef]

4. Janick, J.; Paris, H. The Cucurbit Images (1515-1518) of the Villa Farnesina, Rome. Ann. Bot. 2006, 97, 165-176. [CrossRef]

5. Decker-Walters, D.S.; Walters, T.W. Squash. In The Cambridge World History of Food; Kiple, K.F., Ornelas, K.C., Eds.; Cambridge Univ. Press: Cambridge, UK, 2000; pp. 335-351.

6. Nesom, G.L. New state records for Citrullus, Cucumis, and Cucurbita (Cucurbitaceae) outside of cultivation in the USA. Phytoneuron 2011, 1-7.

7. Kates, H.R.; Soltis, P.S.; Soltis, D.E. Evolutionary and domestication history of Cucurbita (pumpkin and squash) species inferred from 44 nuclear loci. Mol. Phylogenetics Evol. 2017, 111, 98-109. [CrossRef]

8. Adams, G.G.; Imran, S.; Wang, S.; Mohammad, A.; Kok, S.; Gray, D.A.; Channell, G.A.; Morris, G.A.; Harding, S.E. The hypoglycemic effect of pumpkins as anti-diabetic and functional medicines. Food Res. Int. 2011, 44, 862-867. [CrossRef]

9. Różyło, R.; Gawlik-Dziki, U.; Dziki, D.; Jakubczyk, A.; Karaś, M.; Różyło, K. Wheat Bread with Pumpkin (Cucurbita maxima L.) Pulp as a Functional Food Product. Food Technol. Biotechnol. 2014, 52, 430-438. [CrossRef]

10. AlJahani, A.H.; Cheikhousman, R. Nutritional and sensory evaluation of pumpkin-based (Cucurbita maxima) functional juice. Nutr. Food Sci. 2017, 47, 346-356. [CrossRef]

11. Dhiman, K.; Gupta, A.; Sharma, D.; Gill, N.; Goyal, A. A Review on the Medicinally Important Plants of the Family Cucurbitaceae. Asian J. Clin. Nutr. 2012, 4, 16-26. [CrossRef]

12. Aguilera, J.; Park, D.J. Texture-modified foods for the elderly: Status, technology and opportunities. Trends Food Sci. Technol. 2016, 57, 156-164. [CrossRef]

13. Russell, R.M.; Rasmussen, H.; Lichtenstein, A.H. Modified Food Guide Pyramid for people over seventy years of age. J. Nutr. 1999, 129, 751-753. [CrossRef] [PubMed] 
14. Kennedy, E.T.; Ohls, J.; Carlson, S.; Fleming, K. The Healthy Eating Index. J. Am. Diet. Assoc. 1995, 95, 1103-1108. [CrossRef]

15. HEI Scores for Americans. 2015; USDA Food and Nutrition Service; U.S. Department of Agriculture. Available online: www.fns.usda.gov/hei-scores-americans (accessed on 4 March 2020).

16. Gille, D.; Bütikofer, U.; Chollet, M.; Schmid, A.; Altintzoglou, T.; Honkanen, P.; Stoffers, H.; Walther, B.; Piccinali, P. Nutrition behavior of the middle-aged and elderly: Compliance with dietary recommendations of the food pyramid. Clin. Nutr. 2016, 35, 638-644. [CrossRef] [PubMed]

17. Gutierrez, R.M.P. Review of Cucurbita pepo (Pumpkin) its Phytochemistry and Pharmacology. Med. Chem. 2016, 6, 12-21. [CrossRef]

18. Can-Cauich, C.A.; Sauri-Duch, E.; Moo-Huchin, V.M.; Betancur-Ancona, D.; Cuevas-Glory, L.F. Effect of extraction method and specie on the content of bioactive compounds and antioxidant activity of pumpkin oil from Yucatan, Mexico. Food Chem. 2019, 285, 186-193. [CrossRef] [PubMed]

19. Xanthopoulou, M.N.; Nomikos, T.; Fragopoulou, E.; Antonopoulou, S. Antioxidant and lipoxygenase inhibitory activities of pumpkin seed extracts. Food Res. Int. 2009, 42, 641-646. [CrossRef]

20. Shokrzadeh, M.; Azadbakht, M.; Ahangar, N.; Hashemi, A.; Saravi, S.S.S. Cytotoxicity of hydro-alcoholic extracts of Cucurbita pepo and Solanum nigrum on HepG2 and CT26 cancer cell lines. Pharmacogn. Mag. 2010, 6, 176-179. [CrossRef]

21. McGinley, M. Cucurbita pepo. The encyclopedia of Earth. Edible medicinal and non-medicinal plants. In Fruits; Springer: Amsterdam, The Netherlands, 2011; Volume 2.

22. Sarkar, S.; Buha, D. Effect of ripe fruit pulp extract of Cucurbita pepo Linn. in aspirin induced gastric and duodenal ulcer in rats. Indian J. Exp. Boil. 2008, 46, 639-645.

23. Seo, J.S.; Burri, B.J.; Quan, Z.; Neidlinger, T.R. Extraction and chromatography of carotenoids from pumpkin. J. Chromatogr. A 2005, 1073, 371-375. [CrossRef]

24. Dar, A.H.; Sofi, S.A.; Rafiq, S. Pumpkin the functional and therapeutic ingredient: A review. Int. J. Food Sci. Nutr. 2017, 2, 165-170.

25. Zdunić, G.M.; Menković, N.R.; Jadranin, M.B.; Novaković, M.M.; Šavikin, K.P.; Živković, J.Č. Phenolic compounds and carotenoids in pumpkin fruit and related traditional products. Chem. Ind. 2016, 70, 429-433. [CrossRef]

26. Tangney, C.; Rasmussen, H. Polyphenols, inflammation, and cardiovascular disease. Curr. Atheroscler. Rep. 2013, 15, 324. [CrossRef] [PubMed]

27. Albarracin, S.L.; Stab, B.; Casas, Z.; Sutachan, J.J.; Samudio, I.J.; González, J.; Gonzalo, L.; Capani, F.; Morales, L.; Barreto, G.E. Effects of natural antioxidants in neurodegenerative disease. Nutr. Neurosci. 2012, 15, 1-9. [CrossRef] [PubMed]

28. Pogačnik, L.; Silva, R.F.M. Food, polyphenols and neuroprotection. Neural Regen. Res. 2017, 12, 582-583. [CrossRef] [PubMed]

29. Shen, W.; Chen, C.; Guan, Y.; Song, X.; Jin, Y.; Wang, J.; Hu, Y.; Xin, T.; Jiang, Q.; Zhong, L. A pumpkin polysaccharide induces apoptosis by inhibiting the JAK2/STAT3 pathway in human hepatoma HepG2 cells. Int. J. Biol. Macromol. 2017, 104, 681-686. [CrossRef]

30. Alghasham, A.A. Cucurbitacins - a promising target for cancer therapy. Int. J. Health Sci. 2013, 7, 77-89. [CrossRef]

31. Liu, T.; Zhang, M.; Zhang, H.; Sun, C.; Deng, Y. Inhibitory effects of cucurbitacin B on laryngeal squamous cell carcinoma. Eur. Arch. Oto-Rhino-Laryngology 2008, 265, 1225-1232. [CrossRef]

32. Kaushik, U.; Aeri, V.; Mir, S.R. Cucurbitacins - an insight into medicinal leads from nature. Pharmacogn. Rev. 2015, 9, 12-18.

33. Chilczuk, B.; Perucka, I.; Materska, M.; Buczkowska, H. Content of lutein, zeaxanthin, and $\beta$-carotene in lyophilized fruits of selected cultivars of Cucurbita maxima D. Zywn. Nauk. Technol. Jak. 2014, 2, 139-150. (In Polish) [CrossRef]

34. Provesi, J.G.; Amante, E.R. Carotenoids in Pumpkin and Impact of Processing Treatments and Storage. In Processing and Impact on Active Components in Food; Elsevier BV: San Diego, CA, USA, 2015; pp. 71-80.

35. Adedayo, O.R.; Farombi, A.G.; Oyekanmi, A.M. Proximate, mineral and antinutrient evaluation of pumpkin (Cucurbita pepo). J. Appl. Chem. 2013, 4, 25-28.

36. Chiu, H.-F.; Shen, Y.; Venkatakrishnan, K.; Wang, C.-K. Food for Eye Health: Carotenoids and Omega-3 Fatty Acids. In Encyclopedia of Food Chemistry; Elsevier BV: San Diego, CA, USA, 2019; Volume 3, pp. 313-322. 
37. Fissore, E.; Ponce, N.; Stortz, C.; Rojas, A.M.; Gerschenson, L. Characterisation of Fiber Obtained from Pumpkin (Cucumis moschata Duch.) Mesocarp Through Enzymatic Treatment. Food Sci. Technol. Int. 2007, 13, 141-151. [CrossRef]

38. Guillon, F.; Champ, M. Structural and physical properties of dietary fibres, and consequences of processing on human physiology. Food Res. Int. 2000, 33, 233-245. [CrossRef]

39. Wang, P.-C.; Zhao, S.; Yang, B.-Y.; Wang, Q.; Kuang, H.-X. Anti-diabetic polysaccharides from natural sources: A review. Carbohydr. Polym. 2016, 148, 86-97. [CrossRef]

40. Song, Y.; Zhang, Y.; Zhou, T.; Zhang, H.; Hu, X.; Li, Q. A preliminary study of monosaccharide composition and $\alpha$-glucosidase inhibitory effect of polysaccharides from pumpkin (Cucurbita moschata) fruit. Int. J. Food Sci. Technol. 2011, 47, 357-361. [CrossRef]

41. Simpson, R.; Morris, G.A. The anti-diabetic potential of polysaccharides extracted from members of the cucurbit family: A review. Bioact. Carbohydrates Diet. Fibre 2014, 3, 106-114. [CrossRef]

42. Zhang, Y.; Chen, P.; Zhang, Y.; Jin, H.; Zhu, L.; Li, J.; Yao, H. Effects of polysaccharide from pumpkin on biochemical indicator and pancreatic tissue of the diabetic rabbits. Int. J. Boil. Macromol. 2013, 62, 574-581. [CrossRef]

43. Fortis-Barrera, Á.; García-Macedo, R.; Almanza-Perez, J.; Blancas-Flores, G.; Zamilpa-Alvarez, A.; Flores-Sáenz, J.; Cruz, M.; Román-Ramos, R.; Alarcón-Aguilar, F. Cucurbita ficifolia (Cucurbitaceae) modulates inflammatory cytokines and IFN- $\gamma$ in obese mice. Can. J. Physiol. Pharmacol. 2017, 95, 170-177. [CrossRef]

44. Rice-Evans, C.A.; Miller, N.J.; Paganga, G. Structure-antioxidant activity relationships of flavonoids and phenolic acids. Free. Radic. Boil. Med. 1996, 20, 933-956. [CrossRef]

45. Nijveldt, R.J.; Van Nood, E.; Van Hoorn, D.E.; Boelens, P.G.; Van Norren, K.; Van Leeuwen, P. AFlavonoids: A review of probable mechanisms of action and potential applications. Am. J. Clin. Nutr. 2001, 74, 418-425. [CrossRef]

46. De Nisco, M.; Manfra, M.; Bolognese, A.; Sofo, A.; Scopa, A.; Tenore, G.C.; Pagano, F.; Milite, C.; Russo, M.T. Nutraceutical properties and polyphenolic profile of berry skin and wine of Vitis vinifera L. (cv. Aglianico). Food Chem. 2013, 140, 623-629. [CrossRef]

47. Surveswaran, S.; Cai, Y.; Corke, H.; Sun, M. Systematic evaluation of natural phenolic antioxidants from 133 Indian medicinal plants. Food Chem. 2007, 102, 938-953. [CrossRef]

48. Dudonne, S.; Vitrac, X.; Coutiere, P.; Woillez, M.; Mérillon, J.-M. Comparative Study of Antioxidant Properties and Total Phenolic Content of 30 Plant Extracts of Industrial Interest Using DPPH, ABTS, FRAP, SOD, and ORAC Assays. J. Agric. Food Chem. 2009, 57, 1768-1774. [CrossRef]

49. Chekroun-Bechlaghem, N.; Belyagoubi-Benhammou, N.; Belyagoubi, L.; Gismondi, A.; Nanni, V.; Di Marco, G.; Canuti, L.; Canini, A.; El Haci, I.A.; Bekkara, F.A. Phytochemical analysis and antioxidant activity of Tamarixafricana, Arthrocnemummacrostachyum and Suaedafruticosa, three halophyte species from Algeria. Plant. Biosyst. Int. J. Deal. Asp. Plant. Boil. 2019, 153, 843-852.

50. Kumar, N.; Pruthi, V. Potential applications of ferulic acid from natural sources. Biotechnol. Rep. 2014, 4, 86-93. [CrossRef]

51. Hernández, I.A.; Afseth, N.K.; López-Luke, T.; Contreras-Torres, F.F.; Wold, J.P.; Ornelas-Soto, N. Surface enhanced Raman spectroscopy of phenolic antioxidants: A systematic evaluation of ferulic acid, p-coumaric acid, caffeic acid and sinapic acid. Vib. Spectrosc. 2017, 89, 113-122. [CrossRef]

52. Kikuzaki, H.; Hisamoto, M.; Hirose, K.; Akiyama, K.; Taniguchi, H. Antioxidant Properties of Ferulic Acid and Its Related Compounds. J. Agric. Food Chem. 2002, 50, 2161-2168. [CrossRef] [PubMed]

53. Zduńska, K.; Dana, A.; Kołodziejczak, A.; Rotsztejn, H. Antioxidant Properties of Ferulic Acid and Its Possible Application. Ski. Pharmacol. Physiol. 2018, 31, 332-336. [CrossRef] [PubMed]

54. Yang, G.-W.; Jiang, J.-S.; Lu, W.-Q. Ferulic Acid Exerts Anti-Angiogenic and Anti-Tumor Activity by Targeting Fibroblast Growth Factor Receptor 1-Mediated Angiogenesis. Int. J. Mol. Sci. 2015, 16, 24011-24031. [CrossRef]

55. Banjarnahor, S.D.; Artanti, N. Antioxidant properties of flavonoids. Med. J. Indones. 2015, 23, $239-244$. [CrossRef]

56. Gulcin, I. Antioxidant activity of food constituents: An overview. Arch. Toxicol. 2011, 86, 345-391. [CrossRef]

57. Imran, M.; Salehi, B.; Sharifi-Rad, J.; Gondal, T.A.; Saeed, F.; Imran, A.; Shahbaz, M.; Fokou, P.V.T.; Arshad, M.U.; Khan, H.; et al. Kempferol: A Key Emphasis to Its Anticancer Potential. Molecules 2019, 24, 2277. [CrossRef] [PubMed] 
58. Delgado, A.M.; Issaoui, M.; Chammem, N. Analysis of main and healthy phenolic compounds in foods. J. AOAC Int. 2019, 102, 1356-1364. [CrossRef] [PubMed]

59. Kostecka-Gugała, A.; Ledwożyw-Smoleń, I.; Augustynowicz, J.; Wyżgolik, G.; Kruczek, M.; Kaszycki, P. Antioxidant properties of fruits of raspberry and blackberry grown in central Europe. Open Chem. 2015, 13, 1313-1325. [CrossRef]

60. Ezekiel, R.; Singh, N.; Sharma, S.; Kaur, A. Beneficial phytochemicals in potato-A review. Food Res. Int. 2013, 50, 487-496. [CrossRef]

61. Leja, M.; Kaminska, I.; Kramer, M.; Maksylewicz-Kaul, A.; Kammerer, D.; Carle, R.; Baranski, R. The Content of Phenolic Compounds and Radical Scavenging Activity Varies with Carrot Origin and Root Color. Plant. Foods Hum. Nutr. 2013, 68, 163-170. [CrossRef]

62. Nicolle, C.; Simon, G.; Rock, E.; Amouroux, P.; Rámásy, C. Genetic Variability Influences Carotenoid, Vitamin, Phenolic, and Mineral Content in White, Yellow, Purple, Orange, and Dark-orange Carrot Cultivars. J. Am. Soc. Hortic. Sci. 2004, 129, 523-529. [CrossRef]

63. Navarre, D.A.; Goyer, A.; Shakya, R. Nutritional Value of Potatoes. In Advances in Potato Chemistry and Technology; Elsevier BV: San Diego, CA, USA, 2009; pp. 395-424.

64. Kulczyński, B.; Gramza-Michałowska, A. The Profile of Carotenoids and Other Bioactive Molecules in Various Pumpkin Fruits (Cucurbita maxima Duchesne) Cultivars. Molecules 2019, 24, 3212. [CrossRef]

65. Kulczyński, B.; Gramza-Michałowska, A. The Profile of Secondary Metabolites and Other Bioactive Compounds in Cucurbita pepo L. and Cucurbita moschata Pumpkin Cultivars. Molecules 2019, $24,2945$. [CrossRef]

66. Kruczek, M. Pumpkin (Cucurbita sp.) as a source of health-beneficial compounds with antioxidant properties. Dynia (Cucurbita sp.) jakoźródłoprozdrowotnychzwiązków o charakterzeantyoksydacyjnym. Przemyst Chem. 2015, 1, 86-90. (In Polish) [CrossRef]

67. Kulczyński, B.; Gramza-Michałowska, A.; Królczyk, J.B. Optimization of Extraction Conditions for the Antioxidant Potential of Different Pumpkin Varieties (Cucurbita maxima). Sustainability 2020, 12, 1305. [CrossRef]

68. De Paiva, S.A.R.; Russell, R.M. $\beta$-Carotene and Other Carotenoids as Antioxidants. J. Am. Coll. Nutr. 1999, 18, 426-433. [CrossRef] [PubMed]

69. Muñoz-Bernal, Ó.A.; Torres-Aguirre, G.A.; Núñez-Gastélum, J.A.; de la Rosa, L.A.; Rodrigo-García, J.; Ayala-Zavala, J.F.; Álvarez-Parrilla, E. New approach to the interaction between Folin-Ciocalteu reactive and sugars during the quantification of total phenols. TIP Rev. Esp. Cienc. Quim. Biol. 2017, 20, 23-28. (In Spanish)

70. Evans, J.R.; Lawrenson, J.G. Antioxidant vitamin and mineral supplements for slowing the progression of age-related macular degeneration. Cochrane Database Syst. Rev. 2017, 2017, CD000254. [CrossRef] [PubMed]

71. Institute of Medicine (US) Standing Committee on the Scientific Evaluation of Dietary Reference Intakes. Dietary Reference Intakes for Calcium, Phosphorus, Magnesium, Vitamin D, and Fluoride; National Academies Press: Washington, DC, USA, 1997.

72. Russell, R.M.; Beard, J.L.; Cousins, R.J.; Dunn, J.T.; Ferland, G.; Hambidge, K.M.; Suttie, J.W. Dietary Reference Intakes for Vitamin A, Vitamin K, Arsenic, Boron, Chromium, Copper, Iodine, Iron, Manganese, Molybdenum, Nickel, Silicon, Vanadium, and Zinc; A Report of the Panel on Micronutrients, Subcommittees on Upper Reference Levels of Nutrients and of Interpretation and Uses of Dietary Reference Intakes, and the Standing Committee on the Scientific Evaluation of Dietary Reference Intakes Food and Nutrition Board Institute of Medicine; National Academic Press: Washington, DC, USA, 2001.

73. Prasad, A.S. Zinc: Role in immunity, oxidative stress and chronic inflammation. Curr. Opin. Clin. Nutr. Metab. Care 2009, 12, 646-652. [CrossRef] [PubMed]

74. Shahidi, F.; Naczk, M. Phenolics in Food and Nutraceutical: Phenolic Compounds in Fruits and Vegetables; CRC Press: Tulsa, OK, USA, 2004; pp. 131-156.

75. Wang, S.Y.; Zheng, W. Effect of plant growth temperature on antioxidant capacity in strawberry. J. Agric. Food Chem. 2001, 49, 4977-4982. [CrossRef]

76. Ayala-Zavala, J.F.; Wang, S.Y.; Wang, C.Y.; González-Aguilar, G. AEffect of storage temperatures on antioxidant capacity and aroma compounds in strawberry fruit. LWT 2004, 37, 687-695. [CrossRef]

77. Serrano, M.; Guillen, F.; Martínez-Romero, D.; Castillo, S.; Valero, D. Chemical Constituents and Antioxidant Activity of Sweet Cherry at Different Ripening Stages. J. Agric. Food Chem. 2005, 53, 2741-2745. [CrossRef] 
78. Patel, P.R.; Rao, T.V.R. Physiological changes in relation to growth and ripening of khirni [Manilkarahexandra(Roxb.) Dubard] fruit. Fruits 2009, 64, 139-146. [CrossRef]

79. Yang, J.; Gadi, R.; Thomson, T. Antioxidant capacity, total phenols, and ascorbic acid content of noni (Morindacitrifolia) fruits and leaves at various stages of maturity. Micronesica 2011, 41, 167-176.

80. Dinelli, G.; Bonetti, A.; Minelli, M.; Marotti, I.; Catizone, P.; Mazzanti, A. Content of flavonols in Italian bean (Phaseolus vulgaris L.) ecotypes. Food Chem. 2006, 99, 105-114. [CrossRef]

81. Justesen, U.; Knuthsen, P. Composition of flavonoids in fresh herbs and calculation of flavonoid intake by use of herbs in traditional Danish dishes. Food Chem. 2001, 73, 245-250. [CrossRef]

82. Lewandowska, U.; Szewczyk, K.; Hrabec, E.; Janecka, A.; Gorlach, S. Overview of Metabolism and Bioavailability Enhancement of Polyphenols. J. Agric. Food Chem. 2013, 61, 12183-12199. [CrossRef] [PubMed]

83. Pandareesh, M.; Mythri, R.; Bharath, M.S. Bioavailability of dietary polyphenols: Factors contributing to their clinical application in CNS diseases. Neurochem. Int. 2015, 89, 198-208. [CrossRef] [PubMed]

84. Mohammed, S.; Paiko, Y.; Mann, A.; Ndamitso, M.; Mathew, J.; Maaji, S. Proximate, mineral and anti-nutritional composition of Cucurbita maxima fruits parts. J. Chem. Res. 2014, 19, 37-49.

85. Elinge, C.M.; Muhammad, A.; Siaka, A.A.; Atiku, F.A.; Hannatu, A.S.; Peni, I.J.; Yahaya, Y. Nutritional and antinutritional composition of pumpkin (Cucurbita pepo L.) pulp. Adv. Food Energy Secur. 2012, 2, 22-28.

86. Nwaoguikpe, R.N.; Ujowundu, C.O.; Okwu, G.N. The antisickling potentials of four cucurbits (T. occidentalis, C. maxima, C. sativus and C. lonatu). Sch. J. App. Med. Sci. 2013, 1, 191-198.

87. Sánchez-Rangel, J.C.; Benavides, J.; Heredia, J.B.; Cisneros-Zevallos, L.; Jacobo-Velázquez, D.A. The Folin-Ciocalteu assay revisited: Improvement of its specificity for total phenolic content determination. Anal. Methods 2013, 5, 5990. [CrossRef]

88. Benzie, I.; Strain, J. The Ferric Reducing Ability of Plasma (FRAP) as a Measure of "Antioxidant Power": The FRAP Assay. Anal. Biochem. 1996, 239, 70-76. [CrossRef]

89. Apak, R.; Gorinstein, S.; Böhm, V.; Schaich, K.M.; Özyürek, M.; Güçlü, K. Methods of measurement and evaluation of natural antioxidant capacity/activity (IUPAC Technical Report). Pure Appl. Chem. 2013, 85, 957-998. [CrossRef]

90. Apak, R.; Güçlü, K.; Demirata, B.;Özyürek, M.; Celik, S.E.; Bektaşoğlu, B.; Berker, K.I.; Ozyurt, D. Comparative Evaluation of Various Total Antioxidant Capacity Assays Applied to Phenolic Compounds with the CUPRAC Assay. Molecules 2007, 12, 1496-1547. [CrossRef] [PubMed]

91. Özyürek, M.; Güçlü, K.; Apak, R. The main and modified CUPRAC methods of antioxidant measurement. TrAC Trends Anal. Chem. 2011, 30, 652-664. [CrossRef]

92. Brand-Williams, W.; Cuvelier, M.; Berset, C. Use of a free radical method to evaluate antioxidant activity. LWT 1995, 28, 25-30. [CrossRef]

93. Pasławski, P.; Migaszewski, Z.M. The quality of element determinations in plant materials by instrumental methods. Pol. J. Environ. Stud. 2006, 15, 154-164.

94. Yemm, E.W.; Willis, A.J. The estimation of carbohydrates in plant extracts by anthrone. Biochem. J. 1954, 57, 508-514. [CrossRef] [PubMed]

95. Yemm, E.W.; Cocking, E.C.; Ricketts, R.E. The determination of amino-acids with ninhydrin. Anal. 1955, 80, 209. [CrossRef]

96. Owen, A.J. Good Laboratory Practice with a UV-Visible Spectroscopy System; Application Note; Hewlett-Packard Company: Waldbronn, Germany, 1995.

97. Wold, S.; Esbensen, K.; Geladi, P. Principal component analysis. Chemom. Intell. Lab. Syst. 1987, $2,37-52$. [CrossRef]

98. Ward, J.H. Hierarchical grouping to optimize an objective function. J. Am. Stat. Assoc. 1963, 58, $236-244$. [CrossRef]

Sample Availability: Samples of the compounds are not available from the authors.

(C) 2020 by the authors. Licensee MDPI, Basel, Switzerland. This article is an open access article distributed under the terms and conditions of the Creative Commons Attribution (CC BY) license (http://creativecommons.org/licenses/by/4.0/). 